Grant-in-Aid for Scientific Research (S)

Real Estate Markets, Financial Crisis, and Economic Growth

: An Integrated Economic Approach

Working Paper Series No.28

\title{
Lobbying on Regulatory Enforcement Actions: Evidence from Banking
}

Thomas Lambert

J une, 2015

HIT-REFINED PROJ ECT

Institute of Economic Research, Hitotsubashi University

Naka 2-1, Kunitachi-city, Tokyo 186-8603, J APAN

Tel: $+81-42-580-9145$

E-mail: hit-tdb-sec @ier.hit-u.ac.jp

http://www.ier.hit-u.ac.jp/ifn/ 


\title{
Lobbying on Regulatory Enforcement Actions: Evidence from Banking
}

\author{
Thomas Lambert* \\ Université catholique de Louvain \\ Université de Lille - SKEMA Business School \\ Email: thomas.lambert@uclouvain.be \\ Webpage: www.sites.google.com/site/lambertthom
}

\begin{abstract}
There is growing concern, but still little systematic evidence, about the incidence and drivers of lobbying efforts made by the U.S. banking industry. This paper documents the relationships between lobbying, regulatory oversight, and bank risk taking. Using a large sample of commercial and savings banks, I find that lobbying banks are less likely to be subject to a severe enforcement action, suggesting that banks engage in lobbying to gain preferential treatment. Among the lobbying dimensions studied, lobbyists with prior employment in public offices are more effective at reducing the probability of an action, especially in period of intense enforcement activity. These findings are robust to controlling for supervisory ratings and account for endogeneity concerns by employing instrumental variables strategies. I also show an increase in default and credit risk at lobbying banks. Overall, these results appear rather inconsistent with an information-based explanation of bank lobbying, but consistent with the capture theory of regulation.
\end{abstract}

JEL classification codes: D72, G21, G28

Keywords: Banking supervision, enforcement actions, lobbying, moral hazard, risk taking

\footnotetext{
${ }^{*}$ I am grateful to my advisors, Paul Belleflamme and Armin Schwienbacher, for invaluable guidance. I am also indebted to the members of my dissertation committee, Marco Becht, Enrico Perotti, and Paolo Volpin, for advice and encouragement. I especially thank Piotr Danisewicz for many and helpful discussions. I also thank Gilles Chemla, Paolo Colla, Jean-Gabriel Cousin, Hans Degryse, Marc Deloof, and Sophie Shive, as well as seminar participants at ESC Rennes School of Business, Ghent University, SKEMA Business School, and University Paris-Dauphine for comments and suggestions. All remaining errors are my own.
} 


\section{Introduction}

The recent financial crisis demonstrated that regulatory capture and, in particular, weakness in banking regulatory oversight was a key contributing factor in the buildup of risk ahead of the crisis (Kane, 2012). ${ }^{1}$ The three decades leading to the financial crisis were characterized by an enormous growth in the banking industry of the United States. As banks gained importance and wealth, they became in turn more assertive and politically influential. $^{2}$

Lobbying is an important source of rising political influence for the banking industry, affecting the ability of regulators to design proper rules and supervisors to enforce the rules in place. In this context, the regulated industry can allegedly incentivize the regulator to provide favorable treatment, especially when it comes to issue a regulatory enforcement action. Regulatory agencies may indeed impose actions to require that financial institutions undertake corrective measures; this is a crucial micro-prudential supervisory tool to ensure the safety and soundness of the banking system. The preferential treatment, associated with political influence, may in turn magnify the moral hazard problem - that politically active banks can take risks expecting to have favorable treatment when things get bad. This laxity in the enforcement process, in conjunction with the moral hazard problem, created an environment which encouraged excessive risk taking and, ultimately, contributed to the financial meltdown. Despite the continuing debate on this issue and numerous policy prescriptions, little systematic examination of the evidence has been undertaken on the incidence and drivers of lobbying efforts made by the banking industry.

In this paper I attempt to fill this gap by pursuing two goals. First, I empirically examine the relationship between bank lobbying and regulatory enforcement outcome. Two sets of existing theories motivate the examination of this relationship. On the one hand, the decision to lobby politicians or regulatory agencies may be driven by informationtransmission motives. Banks have better information than regulators and partly reveal their information by endogenously choosing their lobbying effort (Grossman and Helpman, 2001, offer an exhaustive literature review). Under this information-based view, lobbying provides regulators with valuable information about banks' financial condition and future outlook. The information-based theory thus predicts that regulatory agen-

\footnotetext{
${ }^{1}$ See also Barth, Caprio, and Levine (2012) and Admati and Hellwig (2013) who provide many examples of failures and gaps in banking regulation and supervision and compelling arguments for why it is harmful.

${ }^{2}$ The experience of financial deregulation over the past three decades in the United States has indeed seen the emergence of an even bigger and more profitable banking industry. During this period, Jayaratne and Strahan (1996), among others, find evidence that intrastate branch banking reforms spurred rapid economic growth. But, as political consequences, these reforms also tended to strengthen an already powerful constituency, the banking industry (see Johnson and Kwak, 2010).
} 
cies are less likely to issue an enforcement action against lobbying banks, which are in turn likely to outperform their non-lobbying peers. On the other hand, regulatory agencies might be laxer in their examinations because they may be captured by banks they supervised, consistently with the theory of regulation put forward by Stigler (1971) and formalized by Peltzman (1976). Under this regulatory capture view, banks lobby to incentivize the regulator and politicians to provide favorable treatment, in exchange of valuable contributions that are used more or less directly to sway voters. ${ }^{3}$ This view also predicts a negative association between lobbying and the probability of an enforcement action, which accordingly involves moral hazard elements. Second, as the merit of these two views is ultimately an empirical question, my second goal is to provide insights into these theories. To do so, I explore the implications of lobbying by banks on their risk-taking behaviors.

I address the first goal by making use of a large (partly hand-collected) dataset of commercial and savings banks from 1999 to 2012. I focus on severe enforcement actions (against institutions) issued by federal agencies in charge of the supervision of commercial and savings banks in the United States - namely, the Office of the Comptroller of the Currency (OCC), the Federal Deposit Insurance Corporation (FDIC), and the Federal Reserve System (Fed). My analysis reveals clear evidence that banks engaged in lobbying are less likely to be subject to a severe enforcement action relative to their non-lobbying peers. Next, I find that the effect is strongest during the banking crisis, suggesting that in period of intense enforcement activity regulatory agencies are more likely to impose an action against non-lobbying banks. In economic terms, an increase of one standard deviation in the dollar amount spent on lobbying corresponds to a decrease of 1.0-2.9 percentage points in the likelihood of getting a severe action, controlling for other factors. Critically, these results are robust to controlling for variables proxying each of the six components of the CAMELS rating (i.e., the U.S. supervisory rating), which serves as decision criteria in the issuance of an enforcement action (see Peek, Rosengren, and Tootell, 1999, for a comprehensive discussion on the importance of the CAMELS ratings). These findings hold regardless whether lobbying is based on lobbying activity, revolving door, or lobbying intensity. As I can only measure the lobbying dimensions regulated under the Lobbying Disclosure Act of 1995 (henceforth LDA), and not the many lobbying practices taking place without being publicly disclosed, my estimates on lobbying can be considered a lower bound of the true effect.

I perform a number of tests to establish the robustness of the results. First, I adopt instrumental variables (IV) strategies to mitigate some of the endogeneity concerns.

\footnotetext{
${ }^{3} \mathrm{An}$ important body of research shows how politicians can exert influence over regulatory agencies by using, among other mechanisms, budgetary control, oversight hearings, and appointment of agents to reward or punish the agencies for decisions that affect their constituencies (see, e.g., McCubbins, Noll, and Weingast, 1999).
} 
The two instruments used are the distance of the bank's headquarters to Washington, D.C. and the initial number of offices held by the lobbying bank. These instruments are valid under both theoretical and statistical grounds. The first instrument proxies for a certain cost of lobbying, while the second for the initial bank size, which is predetermined and not correlated with a bank's enforcement probability prevailing in the following years. Second, although I control for bank size, CAMELS rating, and other financial and demographic factors, it is possible that banks' lobbying activities are correlated with other factors unaccounted for by my control variables, such as the systemic importance of banks. To accommodate this possibility, I conduct a set of tests: I use various specifications including different control variables and also look at subsamples excluding large banks, banks with the best or worst financial condition, and banks headquartered in New York City and Washington, D.C. Third, as I recognize that lobbying decision may not be assigned at random, I also repeat my analysis using matching methods to account for potential selection on observables.

With regard to the second goal, I seek to understand the transmission mechanism by examining the risk-taking behavior of lobbying banks. In this respect, I do find evidence that lobbying banks are associated with higher risk taking. I first examine the aggregate effect of changes in banks' leverage and asset composition on overall bank risk. Following the literature, I rely on the Z-score, a measure of banks' distance to default. In economic terms, I find that lobbying banks increase their default risk (measured by the Z-score) by $5 \%$ of its mean. I also find that lobbying banks tend to follow strategies designed to increase their volatility and credit risk. Overall, this evidence appears to be consistent with a view that moral hazard likely contributed to the increase in risk taking at lobbying banks. In other words, it suggests that the negative link between lobbying and the probability of being subject to an enforcement action fits better with the capture theory of regulation, even though it is hard to firmly establish that some information-based considerations do not drive as well the lobbying decision made by banks.

This paper is related to several strands of the political economy and banking literature. This study belongs to the literature on regulatory design, spanning from the Chicago theory of Stigler (1971) and Peltzman (1976) to the rent-seeking and corruption theories (e.g., Shleifer and Vishny, 1993, 1994). Despite a rich theoretical literature, there is a limited number of papers that document (in developed economies) the various mechanisms through which financial institutions seek to affect the financial outcomes in their favor. For example, Braun and Raddatz (2010) provide international evidence suggesting that banks use their political influence to achieve beneficial regulatory treatment in exchange for rewards in the form of future employment in the banking industry. ${ }^{4}$

\footnotetext{
${ }^{4}$ Related studies show that private interest can pursue weak financial regulation to enjoy favorable access to credit (see, e.g., Perotti and Volpin, 2007).
} 
Kroszner and Strahan (1999) present compelling evidence that pressures from special interest groups account for the pattern of bank branching deregulation of the 1970s and 1980s in the United States. In the context of the recent crisis, Mian, Sufi, and Trebbi (2010) show that the Congress members were more likely to support bank bailout legislation of 2008 when they received higher contributions from the financial sector. Duchin and Sosyura (2012) show that capital allocation to banks under the Troubled Asset Relief Program (TARP) is partly determined by their political connections. Mian, Suf, and Trebbi (2013) find that, during credit-expansion years, mortgage-industry campaign contributions increasingly predict congressional voting behavior on legislation related to housing. Igan and Mishra (2012) examine how spending on lobbying by the financial sector affected deregulation in the run-up to the crisis, while Igan, Mishra, and Tressel (2012) demonstrate that lenders who lobby harder on mortgage issues have higher mortgage credit growth, securitize more aggressively, and end up with higher delinquency rates ex post. ${ }^{5}$

This paper is also connected to studies on moral hazard and bank risk taking. Duchin and Sosyura (2014) study the effect of TARP investments on bank risk taking and credit origination (see also Black and Hazelwood, 2013). The authors show that bailed-out banks initiate riskier loans and shifts assets toward riskier securities after receiving government assistance, suggesting that moral hazard likely contributed to the increase in risk taking as theoretically predicted in Acharya and Yorulmazer (2007), among others. ${ }^{6}$

This paper adds to these literatures in three key aspects. First, this paper helps reconcile these prior findings by illuminating one channel through which lobbying affects risktaking behavior by banks. In particular, I show how banks engage in lobbying to gain preferential treatment, allowing them to "safely" pursue riskier strategies. Second, I address this question in a broad perspective by analyzing banks that represent the vast majority of depository institutions in the United States and that account for a very large portion of overall bank assets, instead of limiting the analysis to large or publicly traded financial institutions. The results of this paper are in this respect directly applicable to the part of the banking industry that is important in terms of economic size, but also in terms of impact on financial stability. Third, to my knowledge, I bring in a micro-prudential dimension not yet systematically explored in other studies, namely the probability of an enforcement action.

I also complement a small number of studies that examine the relationship between special interest politics and regulatory enforcement events. These studies demonstrate

\footnotetext{
${ }^{5}$ Outside the banking industry, Faccio, Masulis, and McConnell (2006) relatedly show how politically connected firms are significantly more likely to be bailed out in distress, yet exhibit worse performance afterwards, consistently with rent-seeking theories.

${ }^{6}$ Outside the U.S. context, see also the empirical analyses of Dam and Koetter (2012) and Gropp, Grundl, and Guettler (2014).
} 
likewise that political connections negatively impact on enforcement outcomes imposed by other regulatory agencies such as the Nuclear Regulatory Commission (Gordon and Hafer, 2005), the Internal Revenue Service (Richter, Samphantharak, Timmons, 2009), or the Securities Exchange Commission (Correia, 2014). Yu and Yu (2012) show that corporate lobbying delays the detection of fraud, illuminating as well the favorable treatment gained by lobbying firms. In the banking literature, Agarwal, Lucca, Seru, and Trebbi (2014) find no evidence that corruption or career prospects in the banking industry are linked to the relative leniency of state banking regulators vis-à-vis federal regulators in assigning CAMELS ratings. Shive and Forster (2014) examine the determinants of revolving door hiring (from one of the six U.S. financial regulators) and its effects on listed financial institutions. They find, among other effects, that new hires are positively associated with the probability of regulatory action from their ex-employer against the institution. ${ }^{7}$ Compared to Shive and Forster (2014) my study takes a somewhat different approach. Rather than focusing on listed financial institutions, I analyze all other individual institutions. Moreover, I concentrate on several other dimensions of lobbying and, importantly, revolving door takes here a somehow different meaning -i.e., the use of lobbyists with past employment in any public offices rather than firms' new hires from regulatory agencies. I capture in this respect another channel of influence through lobbyists' political network.

Finally, this work speaks to the empirical literature on the real effects of banking regulation and supervision. Such work encompasses studies across the globe (Barth, Caprio, and Levine, 2004; Beck, Demirgüç-Kunt, and Levine, 2006) as well as in a single country (Berger and Udell, 1994; Jayaratne and Strahan, 1996; Kroszner and Strahan, 1996). Interestingly, Danisewicz, McGowan, Onali, and Schaeck (2014) find that regulatory enforcement actions, as shocks on bank business activities, adversely affect the local economic activity.

The rest of the paper continues as follows. Section 2 presents the U.S. banking microprudential supervision, provides a brief description of bank lobbying, and develops the hypotheses. Section 3 describes the data and variables. Section 4 contains empirical results. Section 5 concludes.

\section{Institutional Setting and Hypotheses}

In this section I provide some background for the empirical analysis. First, I briefly review the legal and regulatory framework for the application of enforcement actions.

\footnotetext{
${ }^{7}$ Using a large sample of publicly available curricula vitae, Lucca, Seru, and Trebbi (2014) identify evidence of countercyclical net hiring patterns by federal and state banking regulators.
} 
Then, I present the bank lobbying activities in the political system of the United States. I close this section by laying out the hypotheses to be tested.

\subsection{The Enforcement Actions in the U.S. Banking Supervisory Pro- cess}

The United States evolves in a dual federal-state banking system (Blair and Kushmeider, 2006). The OCC, the FDIC, and the Fed share the regulatory and supervisory responsibilities for commercial and savings banks at the federal level, and with the banking departments of the various states. The primary agency in charge with the supervision of a bank is a function of its charter and line of business. Federally chartered banks (usually referred to as national banks) are primarily supervised by the OCC, while state-chartered banks are supervised by the Fed (if members of the Fed) or the FDIC (if not members of the Fed). The Fed has also supervisory authority for all bank holding companies. ${ }^{8}$

The major objective of micro-prudential supervision is to ensure safe and sound banking practices and compliance with banking laws and regulations. To achieve this objective, the supervisory process entails both off-site monitoring and on-site examinations. Offsite monitoring is a "data-driven" approach. This approach uses early-warning models, combining prior examination data and information that banks provide in their Quarterly Report on Condition and Income (or Call Report) filings, to monitor banks between onsite examinations. ${ }^{9}$ In on-site examinations, a bank's primary agency verifies the content of Call Reports and gathers additional in-depth information by meeting the management, reviewing and evaluating its loan portfolio, and reading additional documents from the bank. The regulatory agencies maintain large staffs to conduct periodical on-site examinations (every 12 months, or 18 months if the bank meets certain criteria).

A variety of enforcement actions can be imposed if the agency identifies during its examination any financial weaknesses, managerial problems, or violations of banking laws or regulations. ${ }^{10}$ Agencies may impose informal or formal actions (see below). The enforcement actions require the institution to take corrective measures and, thereby, restore safety and soundness by stabilizing the institution, altering bank practices and

\footnotetext{
${ }^{8}$ The Office of Thrift Supervision, a bureau of the Department of the Treasury, charters and supervises thrifts, which are however not covered by this analysis.

${ }^{9}$ Call Reports provide a snapshot of the reporting institution at the end of each calendar quarter, including a comprehensive set of financial statements and other information relevant to prudential supervision, such as derivatives and off-balance-sheet items, past due and nonaccrual loans, and charge-offs and recoveries.

${ }^{10}$ The management problems leading the initiation of enforcement actions are typically poor loan administration, insufficient corporate planning, inadequate internal control mechanisms, while financial problems leading actions are typically failure to file with regulators, inadequate capital and loan-loss reserves, poor liquidity, inadequate earnings, important volume of poor-quality assets, undue concentration of loans, excessive asset growth, failure to recognize losses, insider payments.
} 
behaviors, and averting potential losses to the deposit insurer. Non-compliance with enforcement actions often carries heavy penalties, including the termination of deposit insurance.

Several types of enforcement actions are available to the regulatory agencies (see Curry, O'Keefe, Coburn, and Montgomery, 1999). On the one hand, informal actions usually request an institution to adopt a board resolution or agree to the provisions of a memorandum of understanding to address the problem. On the other hand, formal enforcement actions, hereafter grouped according to their seriousness, include civil money penalties, prohibition and removal orders, formal written agreements, cease and desist orders, prompt corrective action directives, and deposit insurance threats. Civil money penalties and prohibition and removal orders are usually not issued against the institution itself but against individuals associated with the institution because of violation of laws, regulations, and other written agreements. ${ }^{11}$ In the analysis, I only consider the following formal actions that are publicly disclosed and issued against institutions. First, formal written agreements are bilateral agreements between the bank and the regulator which set out details on actions to be taken or proscriptions to be followed in the written agreement. Written agreements are not followed by a federal court case verdict. Second, cease and desist orders are issued after hearings. They are injunctive-type orders that may be issued when a bank has engaged or is about to engage in an unsafe or unsound banking practice, or a violation of law. A bank subject to such an order is required to follow the proscriptions set out in the order and can be directed to take specified remedial actions. Unlike formal written agreements, cease and desist orders can be enforced in court. Third, prompt corrective actions are automatically imposed on banks with deficient capital levels. These actions impose banks to take corrective measures to restore capital, and require the submission of a capital restoration plan within a predetermined time period. In addition, prompt corrective action framework includes a list of discretionary action that the regulator may impose given the undercapitalization category of the bank (e.g., ban on executive pay, dismissal of board, restrictions on asset growth, prohibition of acquisitions, establishing new branches, issuing new lines of credit). In the analysis, I thus do not consider mandatory prompt corrective actions but instead the issuance of prompt corrective action directives, for which the regulator has the discretion to impose additional actions on the bank. Fourth, deposit insurance threats are the most severe type of enforcement action the regulators can bring before the bank is placed in receivership, which lead to the sale or termination of the bank's charter.

It is also important to note that the examinations culminate in the assignment by a team of examiners of a CAMELS rating, which reflects different degrees of bank health and

\footnotetext{
${ }^{11}$ When illegal actions of individuals threaten the safety and soundness of the institution, a cease and desist order or a formal written agreement against the institution is issued as well (see Ioannidou, 2005).
} 
is scaled between 1 and 5 . Banks with a rating of 1 or 2 are considered with no (few) significant regulatory concerns, whereas those with 3,4 , and 5 ratings present moderate to extreme levels of regulatory concerns. The CAMELS rating is a critical input into numerous types of enforcement actions issued. An informal action is generally directed to institutions receiving a 3 rating, while highly rated (4- and 5-rated) banks are in principles subject to a formal action. The CAMELS rating is however not the only factor conditioning the issuance of an action. The regulator may indeed decide to issue an informal action rather than a formal action: There are instances where the current condition of the bank reflects significant improvement resulting from earlier actions. In other instances, individual or economic circumstances make CAMELS ratings inappropriate (e.g., when the management has been replaced, or in time of crisis when there is higher probability of failure as the health of borrowers and the value of collateral securing loans deteriorate). As noted by Ioannidou (2005), bank size may also be a factor triggering (or not) an action, especially in the presence of asymmetric information. Regulatory agencies and their staffs have thus substantial discretion along the enforcement process-i.e., from the CAMELS grading to the enforcement action decision-making. ${ }^{12}$

\subsection{Bank Lobbying Activities and the Lobbying Disclosure Act of 1995}

Lobbying is the strategic transmission of information in private meetings and venues between interest groups and politicians, their staffs, and agents. In practice, information may have many forms, such as messages, signals, threats, commitments, facts, arguments, statistics, or some combination thereof. ${ }^{13}$ Interest groups have budgets for and spend money on these lobbying activities. The influence of interest groups in the

\footnotetext{
${ }^{12}$ The Center for Public Integrity has published many articles on the hands-off approach of many financial regulators during the past decade. In "FDIC Slow to Pursue Failed Bank Directors, Recover Tax Dollars" (Center for Public Integrity, March 15, 2011 and updated on May 19, 2014), Ben Hallman reports about the United Commercial Bank (UCB), which is based in San Francisco and got a $\$ 300$ million government bailout from the TARP: "[...] examiners had bestowed on UCB a favorable "2" rating on the FDIC scale used to classify a bank's overall condition. That rating denotes "satisfactory performance by management and the board and satisfactory risk management practices," according to FDIC guidelines. The bank received the favorable rating even while examiners identified a number of serious problems, including a large number of exceptions to the bank's lending policy so it could make more loans, and a "combative culture" where management failed to downgrade non-performing loans, according to an FDIC report. [...] The FDIC hasn't taken any public action against former bank officers and directors, though it still has time to do so."

${ }^{13}$ The LDA of 1995 defines a lobbying contact as "any oral or written communication (including an electronic communication) to a covered executive branch official or a covered legislative branch official that is made on behalf of a client with regard to (i) the formulation, modification, or adoption of Federal legislation (including legislative proposals); (ii) the formulation, modification, or adoption of a Federal rule, regulation, Executive order, or any other program, policy, or position of the United States Government; (iii) the administration or execution of a Federal program or policy (including the negotiation, award, or administration of a Federal contract, grant, loan, permit, or license); or (iv) the nomination or confirmation of a person for a position subject to confirmation by the Senate."
} 
political system of the United States is, however, under constant scrutiny. Legislative reforms have been undertaken to respond to the perceived need for transparency and understanding of the activity of special interest groups and their lobbyists. In particular, the LDA of 1995 and its Amendments impose strict disclosure rules for every individual and firm lobbying the Congress and federal agencies. ${ }^{14}$ According to the LDA, lobbyists have to file registration and periodic reports indicating, among other data, the amounts received by clients as compensation for their services, the issue areas and agencies lobbied. $^{15}$

For the purpose of influencing the Congress and agencies, special interest groups also employ a variety of other methods, including campaign contributions, media campaigns, endorsements, and grassroots campaigns. Lobbying is, however, particularly apt to the study of interest groups' political influence. First, lobbying represents by far the most important channel of political influence, especially for the banking industry (see Kerr, Lincoln, and Mishra, 2014). In 2012, the financial sector spent $\$ 488$ million on lobbying, over six times the $\$ 81$ million that they spent on Political Action Committees (PACs) contributions during the congressional cycle 2011-2012 (see Table 1). Historically, no other sector has spent as much money on lobbying and campaign contributions as the financial sector. Table 1 depicts that lobbying expenditures made by the financial sector in 2012 represent about 15 percent of overall lobbying expenditures. Figure 1 (A) shows that insurance companies, securities and investment firms, real estate interests, and commercial banks constitute the bulk of that money. Moreover, the financial industry, including banks, has intensified its lobbying expenditures over the 1999-2012 period (see Figure $1(\mathrm{~B})$ ).

\section{[Insert Table 1 and Figure 1 about here]}

Second, contrasting with campaign contributions, the vast majority of lobbying expenditures reflect a clear economic motive. Campaign contributions are dependent on congressional cycles and may contain ideological and partisan motives (see Ansolabehere, de Figueiredo, and Snyder, 2003), affecting in turn measurements.

Third, one of the most important aspects of lobbying industry is the so-called "revolving door", the career transitions from public services into the lobbying industry. Blanes i Vidal, Draca, and Fons-Rosen (2012) stress the prevalence of former political employees across the lobbying industry. From their sample covering the years 1998-2008, the

\footnotetext{
${ }^{14}$ The LDA defines a lobbyist as "any individual who is employed or retained by a client for financial or other compensation for services that include more than one lobbying contact, other than an individual whose lobbying activities constitute less than 20 percent of the time engaged in the services provided by such individual to that client over a six month period."

${ }^{15}$ Recently, an increasing number of papers have made use of these registration- and transaction-related data on lobbying (see, e.g., Blanes i Vidal, Draca, and Fons-Rosen, 2012; Bertrand, Bombardini, and Trebbi, 2014; see de Figueiredo and Richter, 2014, for a review).
} 
authors report that in total former political employees represent over 60 percent of all lobbyists - i.e., lobbyists who work for lobbying firms and "self-filing" organizations that conduct in-house lobbying activities. These former political employees include congressional staffers as well as former employees of government agencies, executive bodies, or Presidential administrations. Relatedly, half of former congressmen became lobbyists after leaving office. With their political experience, ex-politicians and ex-political employees have developed a network of colleagues and friends that they can later exploit on behalf of their clients. Career concerns in the lobbying industry may in turn have significant effects on the actions taken by serving as politicians or political employees.

\subsection{Hypotheses Development}

Because lobbying represents a pervasive channel through which banks seek political influence and confers a multitude of advantages, banks whose operations and performance are impacted to a greater extent by banking regulation and supervision are more likely to engage in lobbying. As a result, politically active banks may benefit from laxity in the enforcement process for several reasons. First, the capture theory of regulation posits that banks lobby to expect a preferential treatment when it comes to decide on the issuance of a severe enforcement action. Banks may affect enforcement recommendations and priorities by directly lobbying regulatory agencies (OCC, FDIC, Fed), or even the Department of Justice, or elected politicians who have oversight over regulatory agencies. ${ }^{16,17}$ Alternatively, banks may affect indirectly enforcement outcomes by lobbying for favorable regulatory and supervisory environment or business conditions. Indeed, banks spend a fair amount of money to lobby for favorable regulatory conditions, allowing them to start or continue to take excessive risks such as increasing reckless lending practices. $^{18}$

\footnotetext{
${ }^{16}$ The political economy literature generally assumes that politicians are concerned about their reelection prospects and hence about their level of political support. Politicians, seeking reelection, may use a variety of mechanisms to control regulatory agencies, whose activities may affect the political support from their constituencies (McCubbins, Noll, and Weingast, 1999). For example, the legislator can cut the regulatory agency budget to restrain the potential zeal exerted by an agency in trying to control a bank. See, for example, Nathan Kopel, "Consumer Protection Bureau Mired in Politics," Wall Street Journal, June 15, 2011. Elected politicians have also at their disposal other mechanisms to punish or reward regulatory agencies' decisions such as oversight hearings, appointment of agents and threat of turnover.

${ }^{17}$ Equivalently from an empirical standpoint, banks may signal, through a well-financed lobbying force, their willingness to fight the regulator's decision - for example, through subsequent action in the political arena or in the courts-, as regulators have incomplete information about banks' objective function. Gordon and Hafer (2005) predict that the regulator will prefer to avoid pursuing institutions with large lobbying expenditures as it will be costlier in terms of filing and resolving the enforcement action.

${ }^{18}$ The lobbyists' influence on financial regulations has been the subject of a large media coverage; see, for example, Stephen Labaton, "Ailing, Banks Still Field Strong Lobby at Capitol," New York Times, June 4, 2009; Jed Horowitz, "Banks Urge Congress to Extend Crisis-Era Deposit Insurance," Reuters, July 30, 2012; Ben Protess, "Behind the Scenes, Some Lawmakers Lobby to Change the Volcker
} 
Second, under another view, which resonates with the informational lobbying literature, banks lobby to credibly signal information to politicians or regulatory agencies on their financial condition and future outlook. Lobbying mitigates the information asymmetries between both parties and results in better informed enforcement action decisions. Indeed, by lobbying banks may prevent tighter regulation and supervision that would have restricted their profitable opportunities. This information-based view implies that lobbying banks are likely to outperform their non-lobbying peers without specifically taking additional risk. ${ }^{19}$

These reasons, in line with either capture theory of regulation or information-revealing theory, imply that one would observe banks active in lobbying associated with lower probability of receiving an enforcement action. One would also expect that lobbying is associated with greater reduction in the probability of an action when lobbying involves higher expenditures or the existence of revolving doors, as there are higher costs to the politician or regulator of breaking the relationship with the bank. Moreover, once the banking crisis hit and regulatory agencies were forced to file increasing number of enforcement actions, several factors - including lobbying - determine who would be subject to an action and who would not be. Agencies may avoid pursuing lobbying banks in bad times as such banks can be perceived as being costlier to file an enforcement action against them. This motivates the special attention devoted to enforcement outcomes during the crisis.

If banks lobby to increase their chances of preferential treatment, the motive for lobbying involves moral hazard elements. As discussed in the introduction, there is a higher ex ante probability that a given lobbying bank will benefit from lax scrutiny by the regulatory agency in case of problem. When financial or management problems occur, the regulatory agency decides to be laxer in its decision to issue a severe action against banks engaged in lobbying. If there is some consistency in the regulatory agencies' treatment of lobbying banks over time, a lobbying bank has (or signals) an increase in the probability that it will not be subject to a severe action again in case of problem. In turn, this can reduce for example proper corporate governance mechanisms (e.g., less monitoring by outside investors), creating a moral hazard problem. Consequently, banks engaged in lobbying activities are in situation allowing them to take additional risk (hidden action). This moral hazard channel suggests that it is likely to observe

Rule," New York Times, September 20, 2012. See also Glenn Simpson, "Lender Lobbying Blitz Abetted Mortgage Mess," Wall Street Journal, December 31, 2007, who describes that the sought outcome of bank lobbying was the defeat of tighter regulation of the mortgage market that could have reduced reckless lending practices.

${ }^{19} \mathrm{~A}$ different view of informational lobbying — and equivalent from an empirical standpoint-posits that banks lobby to obtain political intelligence to better adapt to changing regulatory environments. More directly, banks can also hire lobbyists to acquire private information about ongoing or impending agencies' actions (see Gao and Huang, 2014). 
an empirical association between banks' lobbying activities and their propensity to take risks, consistently with the capture theory of regulation.

\section{$3 \quad$ Data and Descriptive Statistics}

In this section I discuss the variables used in my analysis and provide details about their construction. The choice of variables is driven by theoretical considerations and data availability. Appendix A summarizes variable definitions.

\subsection{Regulatory Enforcement Actions}

I obtain information about the timing and type of regulatory actions from SNL Financial. I only focus on actions, labelled hereafter as "severe", issued against troubled institutions on the basis of "safety-and-soundness". Severe actions include formal written agreements, cease and desist orders, prompt corrective action directives, and deposit insurance threats. This grouping reflects supervisory practices in the United States. Less severe actions are not used because they are usually issued against individuals affiliated with an institution and thus they are not issued because the financial condition of the institution has been deteriorating. Moreover, state banking regulators may also issue enforcement actions. But these actions are not collected by SNL Financial as they are not provided by all state regulators for the entire sample period. Therefore, I mainly employ a dummy variable equal to one if a severe enforcement action is issued by a federal agency (OCC, FDIC, or Fed) against a given bank in the year the action become effective, and zero otherwise. In unreported robustness tests, I also employ separately dummy variables for each severe action; the results (available upon request) are qualitatively similar to the ones presented in the next section.

Descriptive statistics for my enforcement sample appear in Table 2. In total, I record 2,422 severe enforcement actions and 7,915 less severe actions. The largest number of severe actions consists of cease and desist orders, accounting for 60 percent $(1,462)$ of total severe actions. Formal written agreements accounts for 848 observations, while 104 prompt corrective action directives are identified. Deposit insurance threats make up the remainder, but are observed very marginally during my sample period (8 observations). As expected, more than 60 percent of any actions have been issued after 2007, suggesting that the enforcement activity intensifies in crisis period.

[Insert Table 2 about here] 


\section{$3.2 \quad$ Risk Taking}

I use four balance sheet variables measuring various dimensions of bank risk taking. My primary measure, the Z-score, focuses on overall bank risk. Defined in Appendix A, the Z-score is a frequently used measure of banks' distance to default, which aggregates the effects of leverage and asset composition (see, e.g., Laeven and Levine, 2009; Duchin and Sosyura, 2014). The Z-score is computed as the sum of return on assets (ROA) and the equity-to-asset ratio scaled by the standard deviation of asset returns. Under the assumption of normally distributed bank profits, this score approximates the inverse of the probability of default, with lower values meaning higher chance of default (see Roy, 1952, for a first formalization of the relation). In other words, the Z-score indicates the number of standard deviations a bank's return on assets has to drop below its expected value before equity is depleted and the bank is insolvent.

I complement the Z-score with three measures of bank risk that are respectively based on profit and loan loss ratios (see, e.g., Cebenoyan and Strahan, 2004). The risk variable based on profit ratio is the ROA volatility, which is an estimate of the standard deviation of ROA computed over a three-year rolling time window. The variable based on loan loss ratio is the share of nonperforming loans to total loans. Nonperforming loans include loans that are 90-plus days delinquent and loans in nonaccrual status. This latter measure is a proxy for credit risk, as it reflects the potential adverse exposure to earnings and asset market values owing to deteriorating loan quality. Since a portion of nonperforming loans will result in losses for the bank, a high value for this ratio is associated with higher credit risk. As a further robustness test, I also use the share of nonaccrual loans to total loans as an alternative credit risk measure.

\subsection{Lobbying}

I use lobbying disclosure reports to identify banks that are engaged in lobbying in a given year. The LDA indeed requires lobbyists to register and report information on their activities to the Senate Office of Public Records (SOPR). I use the version of the data compiled by the Center for Responsive Politics (CRP), a non-profit organization based in Washington, D.C. for the promotion of political transparency. ${ }^{20}$ Specifically, the three lobbying variables used in the empirical analysis (see Appendix A for definitions) are constructed with the following information from the CRP lobbying data: the name of the registrant (i.e., the lobbying firm) and the name of the client (in case of a "selffiling" organization, the bank appears as registrant and client); the annual amount the client pays, which is calculated by the CRP by summing the information in semi-annual

\footnotetext{
${ }^{20}$ Details on how CRP has compiled the SOPR information are displayed on their website: www. opensecrets.org.
} 
reports (or quarterly reports after 2007); and the revolving door profile of lobbyists hired by the client.

I merge data obtained from the CRP with the SNL Financial database manually by name to extract information on banks' lobbying activities. The name-matching procedure used (i.e., an algorithm that finds common words) allows me to generate a list of potential matches between the names in the CRP lobbying data and those in the SNL Financial data. I then meticulously check one by one whether the pairs of name strings are actual matches via eyeballing, web searches, and additional information provided in disclosure reports. ${ }^{21}$

In line with prior studies, I consider all lobbying activities at the parent financial institution level rather than the individual bank (subsidiary) level. Individual banks greatly benefit from the lobbying activity of their parent without necessary lobbying on their own. Parents may also lobby on behalf of their subsidiaries. Therefore, for each bank, I assign lobbying information of the parent financial institution. In cases where subsidiaries lobby (and thus file disclosure reports), I attribute its lobbying information to the parent financial institution. This means that the lobbying information for a specific bank may not reflect its original filing with the SOPR, but rather the combined activities of all entities of its group.

It is worth noting that I do not consider expenditures made by industry associations who lobby on behalf of their members. However, if I had to assign a share of the associations' lobbying expenses to each member bank, this would not make a big difference as the amount would appear relatively small compared to amount spent on their own. Moreover, I am unable to include those lobbying expenditures since associations normally do not disclose membership information. This limitation of the data implies that I underestimate some bank's actual lobbying activities.

I identify 360 banks that are active in lobbying in any of the years from 1999 to 2012; this corresponds to 1,355 lobbying bank-year observations. Table 3 reports the time distribution of lobbying banks. The lobbying sample exhibits similar regularities than what is presented in section 2.2 for the entire financial sector. Banks are increasingly active in lobbying during the sample period. The average amount spent intensified from about $\$ 800$ thousand in 1999 to $\$ 1.4$ million in 2012. While the number of lobbying banks is relatively small compared to non-lobbying banks (1.24 percent of bank-year observations), it represents a significant fraction of total amount spent on lobbying by the financial sector.

\footnotetext{
${ }^{21}$ This information available on CRP website is not user-friendly (one has to click on each bank to obtain details). Also, I often go over the individual disclosure reports (in pdf format on both SOPR and CRP websites) to cross-check the information.
} 


\section{[Insert Table 3 about here]}

Moreover, I manually collect from CRP the issue areas and the name of agencies lobbied. Untabulated statistics from the lobbying sample show that banks lobbied an average of 24 agencies per year, while they only lobbied an average of one agency responsible for supervising commercial and savings banks (i.e., FDIC, OCC, or Fed). Although this is relatively low, in the vast majority of cases banks appear to lobby the Congress, who oversees these agencies. In more than fifty percent of cases, bank lobbying activities are related to finance-specific issues (i.e., accounting, banking, bankruptcy, and financial institutions issues). Lastly, banks' lobbying status is highly persistent over time. The correlations between the lobbying variables and their respective lagged value range from 81.8 to 94.4 percent. This is consistent with Kerr, Lincoln, and Mishra (2014), among other studies, who report a 92 percentage probability that a firm will lobby in a given year conditional on lobbying in the prior year.

\subsection{Financials and Demographics}

To control for banks' financial condition and performance, I follow the CAMELS rating system employed by U.S. regulatory agencies in their decision to initiate actions against institutions. The CAMELS rating derives its name from the six components that are evaluated: Capital adequacy, Asset quality, Management quality, Earnings, Liquidity, and Sensitivity to market risk. Each of the six components is rated by regulators and the final rating is on a scale of 1 to 5 . Because an announcement by a regulator that a bank has a high CAMELS rating (meaning a high probability of failure) could be extremely detrimental to the institution, individual banks' CAMELS ratings are highly classified (see Peek, Rosengren, and Tootell, 1999). I thus need to introduce proxy variables for each of the six components. Similar to Duchin and Sosyura (2012, 2014), my choice of proxy variables is guided by financial ratios and management information that evaluate banks on similar components and available in Call Reports. I obtain Call Reports data for all commercial and savings banks in the United States between 1999 and 2012 from SNL Financial. These reports are also used for the other financial data used in my analysis. Appendix A offers detailed descriptions of each CAMELS rating proxy variable, while Table 4 presents descriptive statistics.

In addition to CAMELS rating proxy variables, I also control for the following set of financial and demographic factors: Deposit-to-asset ratio (reliance on deposits), debt-toequity ratio (leverage), total core deposits (size of banks' stable source of funds), total assets (bank size), and age.

[Insert Table 4 about here] 


\subsection{Additional Descriptive Statistics}

The full sample consists of 11,115 banks and covers the time period from 1999 through 2012 (108,876 bank-year observations). ${ }^{22}$ The types of banks included are the ones supervised by the OCC, the FDIC, or the Fed; that is, mainly commercial banks, but savings banks and bank holding companies (not consolidated data) are also included. In Table 4, I present descriptive statistics on the main variables for the full sample. These statistics provide sample moments that will be useful for interpreting the magnitude of my regression coefficients. Figure 2 also shows that there is no systematic clustering of states where regulatory enforcement actions and lobbying activities took place.

In Table 5, I describe the characteristics of banks subject to an enforcement action. Compared to banks not subject to an action, those whose regulator issued an action against are, as expected, significantly less healthy in terms of capital adequacy, asset quality, management quality, and earnings; this is, however, not the case for two CAMELS components: Liquidity and Sensitivity to market risk. Along related dimensions, banks subject to an action are more leveraged and have a lower Z-score, meaning that they are more likely to default. The regulatory agencies also tend to issue a severe action to banks that are bigger and younger.

\section{[Insert Table 5 and Figure 2 about here]}

Table 5 also provides preliminary evidence that lobbying banks are less often subject to an enforcement action. Lobbying expenditures are 5 percentage points higher in banks that are not subject to an action, although the difference just fails to be statistically significant at the 10 percent level $(p$-value $=0.11)$. This suggests that lobbying intensity is associated with lax enforcement outcome. I draw similar conclusions when I compare the enforcement outcome based on lobbying and revolving door dummy variables. As lobbying banks are also different on dimensions other than the enforcement outcome, I now turn to examine this relationship in the multivariate settings to follow.

\section{Empirical Results}

This section contains the regression results. In the following I analyze the relationship between bank lobbying and enforcement outcome in greater depth. The moral hazard implications of bank lobbying follow with the presentation of regression results relating lobbying and risk taking.

\footnotetext{
${ }^{22}$ I have removed observations that correspond to outlier banks.
} 


\subsection{Do Lobbying Banks Benefit from Laxity in the Enforcement Pro- cess?}

To study the relationship between bank lobbying and the probability of getting a severe enforcement action, I estimate the following logit model:

$$
\operatorname{Prob}\left(Y_{i t} \mid \boldsymbol{X}_{\boldsymbol{i t}}\right)=F\left(\alpha+\boldsymbol{X}_{\boldsymbol{i t}} \boldsymbol{\beta}\right),
$$

where $F(\cdot)$ is the cumulative logistic distribution. ${ }^{23} Y_{i t}$ is equal to one if the regulatory agency issues a severe enforcement action on bank $i$ at time $t$, and is equal to zero otherwise. $\alpha$ is a constant term. $\boldsymbol{X}_{\boldsymbol{i t}}$ contains a variety of factors, including time and state dummies, time-varying control variables, and one of the three measures of lobbying (Lobbying dummy, Revolving door dummy, and the natural logarithm of Lobbying expenditures). In all specifications, the set of time-varying control variables includes the CAMELS rating proxies (Capital adequacy, Asset quality, Management quality, Earnings, Liquidity, Sensitivity to market risk) as well as Deposit-to-asset ratio, Leverage, the natural logarithm of Total core deposits, Size, and Age. As already shown in Table 4 , there are few enforcement action events compared to zeros ("nonevents"); the event of an action occurs in about 2 percent of all bank years. Logistic regression coefficients are biased downwards in rare events data. Following King and Zeng's (2001) recommendations, I correct these biases by analyzing the data using rare events logit model. My results are stronger following their recommendations, and are unreported for brevity. In tables, I report standard logit models to be conservative. All standard errors are clustered by bank.

A few comments are in order. First, I would ideally control for the unobservable bank specific effect by estimating the logit model (1) including bank fixed effects. However, the estimation of the bank fixed effects coefficients in my nonlinear panel data setting introduces an incidental parameters problem discussed by Neyman and Scott (1948) and reviewed by Lancaster (2000). This problem of finding consistent estimators in nonlinear models occurs because the number of fixed effects grows without bound, but the amount of information available for their estimation is limited, especially in settings with short time span and many fixed effects. Both the fixed effects and coefficients on other variables (i.e., $\boldsymbol{\beta}$ ) become biased in such setting. For nonlinear panel data models, it is not possible to get rid of the fixed effects by taking differences or performing within transformation (see Hsiao, 2003). My results are however robust to the use of a linear probability model with bank fixed effects, and are reported in Appendix Table B1. Second, it is also worth emphasizing that I do not observe much variation of my lobbying measures within banks, as discussed in section 3.3. The clear advantage of fixed-effect

\footnotetext{
${ }^{23}$ The estimation results are qualitatively similar if a probit model is used.
} 
model then comes at a certain price and the drawback results from its inefficiency in estimating the effect of variables that have very little within variance.

\section{[Insert Table 6 about here]}

Models (1) to (3) of Table 6 report the base regression results for the full sample. The results of the regression analysis are consistent with the univariate evidence presented in the previous section. As shown in Models (1)-(3), the measures of lobbying are negatively associated with the likelihood of getting a severe enforcement action. The economic magnitudes of lobbying are meaningful. To facilitate the estimation of magnitudes, Table 6 reports average marginal effects. Based on Models (1)-(3), I find that banks active in lobbying are 0.8 percentage points less likely to receive a severe enforcement action. Regarding revolving door, the effect is also more significant (statistically and economically). I find that banks employing revolving door lobbyists are 1.1 percentage points less likely to be subject to an action. Similarly, an increase of $\$ 1$ million in the amounts spent on lobbying is estimated to reduce the likelihood of an action by 3.3 percentage points.

Next, I restrict the sample to the period covered by the last U.S. banking crisis. During this period, which is characterized by an intensive enforcement activity, the regulatory agencies may face higher constraints, affecting their decision to issue an enforcement action against particular banks. Models (4) to (6) of Table 6 show that the three measures of lobbying tend to make an action much less likely during the 2007-09 banking crisis. From Models (4) to (6), it can be seen that the impact of lobbying is statistically and economically stronger. The economic magnitude of lobbying and revolving door dummies are more than twice as big as for the full sample. As for the lobbying intensity, an increase of $\$ 1$ million in the amounts spent on lobbying corresponds to a 9.4 percentage points reduction in the likelihood of an action. As a banking crisis is defined differently by different scholars (Reinhart and Rogoff, 2011; Laeven and Valencia, 2013), I also consider other banking crisis periods fitting with alternative (less restrictive) definitions. Reported in Appendix Table B2, the results for the various samples fitting with these alternative definitions are even stronger statistically and economically. This suggests that regulatory agencies appear to be even more influenced by lobbying during intensive crisis-related enforcement activity.

The evidence from financial and demographic control variables indicates that banks are more likely to receive a severe enforcement action if they are more leveraged, have higher deposit-to-asset ratio, and, in some specifications, have lower levels of core deposits and are larger and younger. The likelihood of a severe enforcement action is higher if banks present worst financial and management conditions as reflected in higher rating for most of the CAMELS components. For example, based on Model (1), a one standard 
deviation drop in the Tier 1 risk-based capital ratio (Capital adequacy) corresponds to a 1.2 percentage points increase in the probability of receiving a severe enforcement action. Again according to Model (1), a one standard deviation drop in ROA (Earnings) is associated with a 2.1 percentage points increase in the likelihood of a severe enforcement action.

Overall, these results strongly characterize the issuance of a severe enforcement action as being partly driven by banks' lobbying force. This suggests that lobbying banks receive a more favorable treatment by regulatory agencies. I now turn to further address endogeneity concerns about the lobbying variables.

\subsection{Addressing Endogeneity}

As banks are heterogeneous along many different dimensions, most of which are difficult to observe and quantify, my results might be impaired if there is an omitted variables problem that causes inference to break down. As an example, the confidential (unobserved) component of the supervisory data (CAMELS ratings) may be responsible of the results as it can affect both enforcement and lobbying decisions. Also, it can plausibly be argued that banks lobby because they expect to get a severe action given their financial or managerial problems, raising some doubts that the causality runs in the direction outlined (i.e., from lobbying to enforcement outcome) rather than the other way around. As these endogeneity concerns may weaken the conclusions drawn in the previous section, I rule this out by instrumenting the lobbying variables.

I employ two instruments. As a first instrument, I consider the distance (in $\mathrm{km}$ ) of the bank's headquarters to Washington, D.C., a proxy for a certain cost of lobbying. Because the "business" of lobbying at the federal level is intricately intertwined with life in Capitol Hill, I argue that the cost of lobbying is an increasing function of the distance to Washington, D.C. I can arguably assume that the distance to Washington, D.C. affects a bank's lobbying decision, but has no independent effect on the outcome under study. As a second instrument, I use the initial (in 1998) number of offices held by the lobbying bank. Indeed, larger organizations are more likely to lobby (Bombardini, 2008). This second instrument is unlikely to be correlated with enforcement decisions prevailing in the sample years as the initial number of offices is predetermined.

As my empirical models are characterized by binary outcome and treatment variables, ${ }^{24}$ I adopt two common IV strategies to estimating causal effects in such models (see, e.g., Angrist and Pischke, 2009: 197-205). The first strategy computes maximumlikelihood estimates (MLE) of a bivariate probit model, which assumes that the outcome

\footnotetext{
${ }^{24}$ That is, in the models in which the independent variables of interest are Lobbying dummy and Revolving door dummy.
} 
and treatment variables are each determined by latent linear index models with jointly normal error terms. The second strategy I use disregards the binary structure of the outcome and treatment variables and presents two-stage least squares (2SLS) estimates of a linear model. Table 7 contains the estimation results from these two strategies relying on the instruments introduced above as the source of identification.

I first outline the bivariate probit model, in which the first stage of the latent index is linear in covariates and excluded instruments. Suppose that a bank's decision to lobby can be written as:

$$
L_{i t}=1\left[\boldsymbol{X}_{i t} \boldsymbol{\beta}_{\mathbf{1}}+\gamma_{\mathbf{1}} \boldsymbol{Z}_{i t}+v_{i t}>0\right],
$$

where $\boldsymbol{X}_{i t}$ and $\boldsymbol{Z}_{i t}$ respectively contain the covariates and the instrumental variables, and $v_{i t}$ is a random error term. The second stage is similar to equation (1); the outcome variable of interest, $Y_{i t}$ (Severe action dummy), is determined by the latent index:

$$
Y_{i t}=1\left[\boldsymbol{X}_{i t} \boldsymbol{\beta}_{\mathbf{2}}+\boldsymbol{\delta}_{\mathbf{2}} \boldsymbol{L}_{i t}+\epsilon_{i t}>0\right]
$$

where $\epsilon_{i t}$ is a second random error term. To allow for the possibility that the unmeasured random determinants of lobbying are correlated with unmeasured random determinants of the issuance of a severe action, I assume that $\epsilon_{i t}$ and $v_{i t}$ are distributed as bivariate normal with mean zero, each has unit variance, and $\rho=\operatorname{Corr}\left(\epsilon_{i t}, v_{i t}\right)$. The system is identified by assuming $\left(\epsilon_{i t}, v_{i t}\right)$ is independent of $\boldsymbol{Z}_{i t}$. Because both decisions I model are dichotomous, there are four possible states of the world $\left(Y_{i t}=0\right.$ or 1 and $L_{i t}=0$ or 1). The likelihood function corresponding to these events is therefore a bivariate probit.

In columns (1) and (2), Panel A, I present the MLE bivariate probit estimates for Lobbying dummy and Revolving door dummy, respectively, using the Distance to D.C. and Initial market size as instruments and the same right-hand side variables I use for equation (1). In both models the MLE estimates of the marginal effect of lobbying and revolving door dummies are clearly in line with estimates from Table 6 , though they give slightly larger estimates: -0.013 versus -0.008 for Lobbying dummy and -0.011 versus 0.014 for Revolving door dummy. The MLE estimates of the correlation coefficients $\rho$ are positive and statistically insignificant.

The bivariate probit model is not only way to go. As advocated by Angrist and Pischke (2009), a viable, less complicated, alternative is 2SLS model one could estimate if all potentially endogenous variables were continuous. If I ignore the fact that the dependent variable is binary and estimate

$$
Y_{i t}=\alpha+\boldsymbol{X}_{i t} \boldsymbol{\beta}+\delta L_{i t}+\epsilon_{i t}
$$


with IV, the estimates of $\delta$ is again negative and statistically significant at conventional levels. The 2SLS estimates, reported in columns (3) and (4), Panel A, are quite a bit larger in magnitude than the MLE estimates. Importantly, I report evidence on the validity of instruments in Panel B. If Distance to D.C. and Initial market size are valid, then (1) they must be determinants of the decision to lobby (relevance condition), but (2) they must not be determinants of the decision to issue a severe enforcement action, that is, they must be uncorrelated with $\epsilon_{i t}$ (exclusion condition). From Panel $\mathrm{B}$, one can note that both instruments enter significantly with the expect sign in the first-stage regression. The first-stage $F$-statistics, reported at the bottom of Panel B, are well above the critical value for a 2SLS estimation with two instruments, meaning that my instruments are strong and thus satisfy the relevance condition. Although it is easy to show that the instruments meet the first condition, the second condition is not testable directly. However, I test for overidentifying restrictions and $p$-values of the Hansen $J$-statistics are higher than $10 \%$ in both cases.

In the case of the continuous variable, Lobbying expenditures, I fit an IV probit model using MLE. Column (5) shows that the coefficient on Lobbying expenditures has the same sign and level of significance as its counterpart in Table 6. The Wald test at the bottom of the table, testing whether the correlation coefficient $\rho$ is equal to zero, reports an insignificant statistic.

\section{[Insert Table 7 about here]}

\subsection{Robustness and Alternative Explanations}

In this section I evaluate the robustness of the results presented so far to alternative explanations. I start by considering different measures of banks' financial and managerial conditions and then I address issues related to unspecified or unobservable variables correlated to the lobbying measures. Table 8 and 9 summarize these robustness tests.

First, I would like to check the robustness of my results to different choice of measures proxying the CAMELS components. I also consider an alternative measure for Leverage and Total core deposits, next to the CAMELS components. These alternative measures are discussed in Appendix A. Each CAMELS component is, however, not subject to an alternative measure due to data availability. Column (1) of Table 8 (Panels AC) reports the estimation results with the new set of control variables. The qualitative conclusions for all lobbying variables remain unchanged, suggesting that my main results are consistent across different measures of financial and managerial conditions.

Second, I check whether my findings are not confined to a subset of particular banks. Specifically, I gauge the sensitivity of my results to the exclusion of banks with the 
best or worst financial condition. In columns (2) and (3), I exclude the top (bottom) $25 \%$ of the banks with best (worst) financial condition, as proxied by banks' capital adequacy. Excluding banks with best or worst financial health does not affect my results, except in column (3), Panel C, where the variable Lobbying expenditures just fails to be statistically significant at the $10 \%$ level. Third, in column (4), I exclude banks headquartered in New York City and Washington, D.C. to evaluate whether my results are not driven by a subset of banks with strong connections to Congress and regulatory agencies, given their critical localization. The findings hold after eliminating banks located in these centers of influence regardless the lobbying variables used.

Fourth, I consider the issue of systemic importance. My results can be driven by a subset of large banks, which would receive unconditionally preferential treatment irrespective of their lobbying efforts given their systemic risk. To address this possibility, I exclude the largest banks in my sample. Column (5) reports the results of estimating the logit model of the issuance of a severe enforcement action after eliminating the top decile of banks in terms of asset size. My results on each lobbying variable are hardly altered. In column (6) I also allow for various functional forms of the relation between size and systemic importance. In particular, I introduce in the model higher-order powers of Size-i.e., Size squared and Size cubed. All qualitative and quantitative conclusions hold.

\section{[Insert Table 8 about here]}

Fifth, I perform an additional test to evaluate the robustness of my results to controlling for non-random assignment. To do so, I construct matched subsamples of lobbying (treatment group) and non-lobbying banks (control group) to rule out that the results are driven by the observable composition of these two groups. For each of the treatment and control groups, I compute a propensity score via logit model, in which the dependent variable is Severe action dummy. My choice of independent variables includes economically meaningful factors such as Deposit-to-asset ratio, Leverage, Size, Age, year dummies, and state dummies. It is worth emphasizing that this test also allows to distilling the effect of lobbying from that of systemic importance, as asset size alone may not be sufficient to capture systemic importance. Table 9 summarizes the results from the various matching used - namely, nearest neighbor matching and kernelbased matching (see Heckman, Ichimura, and Todd, 1997, 1998, for greater details). One can see that lobbying banks consistently receive less severe enforcement actions. The size of the treatment effect is here greater than in Table 6. The estimates for Lobbying dummy (Revolving door dummy) range from -0.011 to -0.016 (from -0.013 to -0.018), while statistical significance reaches the $1 \%$ level in almost all specifications.

Together these results suggest that there is an economically non-negligible treatment difference in terms of issuance of enforcement actions between lobbying and non-lobbying 
banks. I now turn to examine the reasons why banks engage in lobbying in order to benefit from such favorable treatment.

\section{[Insert Table 9 about here]}

\subsection{Risk Taking in Lobbying Banks}

So far, I have shown that bank lobbying reduces the likelihood of a severe enforcement action. Lobbying activities influence the way banks are run, especially regarding how much risk they take. In this section I pursue my second goal of gaining a deeper insight into lobbying banks' risk taking behavior. One possibility, involving moral hazard elements, is that the lobbying process acts as a shield from supervisory scrutiny leading banks to take more risk. Another possibility is that the bank lobbying process is to better inform regulators and to guide them in their corrective measures decisions. Under this latter view, lobbying banks are more likely to be associated with lower risk. Indeed, the lobbying process facilitates the transmission of prescriptions from regulators in terms of bank risk. Table 10 presents the results.

The first outcome I consider is the measure of default risk, namely the Z-score. I take the natural logarithm of this score given its skewed distribution (see Figure 3). I then complement my analysis with bank risk measures based on profits and loan loss ratios. Each column reports the results of panel regressions of bank risk, where the dependent variables include the Z-score, ROA volatility, nonperforming loans ratio, and nonaccrual loans ratio, on the three measures of lobbying. Control variables are Deposit-to-asset ratio, Total core deposits, Size, Age, year and state fixed effects. Standard errors are clustered by bank. The evidence across the columns indicates a statistically and economically significant increase in risk taking at lobbying banks.

\section{[Insert Table 10 and Figure 3 about here]}

In column (1), I show that bank lobbying is associated with higher default risk, an effect that is significant for all lobbying variables (Panels A-C). Lobbying banks show a decrease in the Z-score of 0.233 relative to non-lobbying banks with similar characteristics, which is $5 \%$ of its mean value (in logarithm form) in Table 4-recalling that a smaller estimated Z-score implies more default risk. The effect on banks employing revolving door lobbyists is statistically and economically similar. Regarding lobbying intensity, a $10 \%$ increase in lobbying expenditures implies $18.5 \%$ drop in the Z-score. In column (2), I also consistently find across Panels A-C that lobbying banks have higher ROA volatility than non-lobbying banks.

To further investigate the analysis of risk, I turn to the risk associated with one key 
channel of bank operations: credit risk. Column (3) shows that lobbying banks are associated with higher nonperforming loans ratio. For example, Panel A shows that lobbying banks are associated with nonperforming loans ratio that is 0.005 higher than non-lobbying banks, which is $1.2 \%$ of the mean of the variable (taken in logarithm). The results in column (4) mirror those found in column (3) for the nonaccrual loans ratio, and are very similar.

For robustness purposes, I also repeat the analysis on bank risk for alternative model specifications and subsamples as in Table 8. In particular, I extend the set of control variables to the CAMELS rating proxies. The results are summarized in Appendix Table B3 and do not affect the conclusions drawn. ${ }^{25}$

In summary, lobbying banks, which are less likely to be subject to severe action, tend to engage in additional risk taking - namely, default, volatility, and credit risk. These results appear, therefore, consistent with the capture theory of regulation à la Stigler (1971) and Peltzman (1976), but rather inconsistent with an explanation echoing the informational lobbying literature (Grossman and Helpman, 2001).

\section{Conclusion}

In the aftermath of the financial crisis, the political influence of the banking industry and, in particular, their lobbying efforts have been blamed by many observers and commentators for being responsible of failures and gaps in banking regulation and supervision. Because of the difficulty of measuring political influence, anecdotes mainly drive this general perception. This paper presents systematic bank-level evidence on the link between bank lobbying and the issuance of enforcement actions, a crucial aspect of banking micro-prudential supervision. Using a large sample of commercial and savings banks, I find that banks engaged in lobbying activities have lower probabilities of receiving an enforcement action-being either a formal written agreement, cease and desist order, prompt corrective action directive, or deposit insurance threat. All dimensions of lobbying studied point in the direction of a significant negative impact of lobbying on the issuance of a severe action. The effect identified is stronger during the banking crisis, suggesting that regulators face higher constraints in periods of intense regulatory activity and are more politically influenced. The evidence on the propensity of taking risk at lobbying banks sheds light on the reasons why banks lobby to gain preferential treatment. Broadly consistent with the Stigler-Peltzman view of regulation, my findings suggest (1) that the supervisory process is not immune to the political influence of banks

\footnotetext{
${ }^{25}$ For brevity, Appendix Table B3 only reports the results for Lobbying dummy as an independent variable of interest. The results (available upon request) are qualitatively similar for Revolving door dummy and Lobbying expenditures.
} 
and (2) that regulatory and supervisory distortions induced by lobbying outweigh the welfare-enhancing role of the lobbying process in terms of information transmission. Understanding and quantifying further these distortions induced by bank lobbying remains a fruitful area of future research.

From a policy perspective, my findings have implications for the redesign of banking regulation in the United States and in other part of the world, especially within the European Union. While my findings should not be interpreted as evidence for banning lobbying, they decisively point in the direction of a need for tighter rules governing lobbying activities. This implies that policymakers should advocate for greater transparency but also address the pervasive dominance of the banking industry and their lobbyists as a special interest group.

\section{References}

[1] Acharya, Viral, and Tanju Yorulmazer, 2007, Too Many to Fail - An Analysis of Time Inconsistency in Bank Closure Policies, Journal of Financial Intermediation $16,1-31$.

[2] Admati, Anat, and Martin Hellwig, 2013, The Bankers' New Clothes: What's Wrong with Banking and What to Do About It (Princeton University Press, Princeton).

[3] Agarwal, Sumit, David Lucca, Amit Seru, and Francesco Trebbi, 2014, Inconsistent Regulators: Evidence from Banking, Quarterly Journal of Economics 129, $889-938$.

[4] Angrist, Joshua, and Jörn-Steffen Pischke, 2009, Mostly Harmless Econometrics: An Empiricists Companion (Princeton University Press, Princeton).

[5] Ansolabehere, Stephen, John de Figueiredo, and James Snyder, 2003, Why is There so Little Money in Politics? Journal of Economic Perspectives 17, 105-130.

[6] Barth, James, Gerard Caprio, and Ross Levine, 2004, Bank Supervision and Regulation: What Works Best? Journal of Financial Intermediation 13, 205-248.

[7] Barth, James, Gerard Caprio, and Ross Levine, 2012, Guardians of Finance: Making Regulators Work for Us. (MIT Press, Cambridge).

[8] Beck, Thorsten, Asli Demirgüç-Kunt, and Ross Levine, 2006, Bank Supervision and Corruption in Lending, Journal of Monetary Economics 56, 2131-2163. 
[9] Berger, Allen, and Gregory Udell, 1994, Did Risk-Based Capital Allocate Bank Credit and Cause a "Credit Crunch" in the United States? Journal of Money, Credit and Banking 26, 585-628.

[10] Bertrand, Marianne, Matilde Bombardini, and Francesco Trebbi, 2014, Is It Whom You Know or What You Know? An Empirical Assessment of the Lobbying Process, American Economic Review, forthcoming.

[11] Black, Lamont, and Lieu Hazelwood, 2013, The Effect of TARP on Bank RiskTaking, Journal of Financial Stability 9, 790-803.

[12] Blair, Christine, and Rose Kushmeider, 2006, Challenges to the Dual Banking System: The Funding of Bank Supervision, FDIC Banking Review 18, 1-20.

[13] Blanes i Vidal, Jordi, Mirko Draca, and Christian Fons-Rosen, 2012, Revolving Door Lobbyists, American Economic Review 102, 3731-3748.

[14] Bombardini, Matilde, 2008, Firm Heterogeneity and Lobby Participation, Journal of International Economics 75, 329-348.

[15] Braun, Matías, and Claudio Raddatz, 2010, Banking on Politics: When Former High-Ranking Politicians Become Bank Directors, World Bank Economic Review $24,234-279$.

[16] Cebenoyan, Sinan, and Philip Strahan, 2004, Risk Management, Capital Structure and Lending at Banks, Journal of Banking and Finance 28, 19-43.

[17] Correia, Maria, 2014, Political Connections and SEC Enforcement, Journal of Accounting and Economics 57, 241-262.

[18] Curry, Timothy, John O'Keefe, Jane Coburn, and Lynne Montgomery, 1999, Financially Distressed Banks: How Effective are Enforcement Actions in the Supervision Process? FDIC Banking Review 12, 1-18.

[19] Dam, Lammertjan, and Michael Koetter, 2012, Bank Bailouts and Moral Hazard: Evidence from Germany, Review of Financial Studies 25, 2343-2380.

[20] Danisewicz, Piotr, Danny McGowan, Enrico Onali, and Klaus Schaeck, 2014, The Real Effects of Regulatory Enforcement Actions: Evidence from U.S. Counties, Working Paper, Bangor University.

[21] de Figueiredo, John, and James Snyder, 2014, Advancing the Empirical Research on Lobbying, Annual Review of Political Science 17, 163-185.

[22] Duchin, Ran, and Denis Sosyura, 2012, The Politics of Government Investment, Journal of Financial Economics 106, 24-48. 
[23] Duchin, Ran, and Denis Sosyura, 2014, Safer Ratios, Riskier Portfolios: Banks' Response to Government Aid, Journal of Financial Economics 113, 1-28.

[24] Faccio, Mara, Ronald Masulis, and John McConnell, 2006, Political Connections and Corporate Bailouts, Journal of Finance 61, 2597-2635.

[25] Gao, Meng, and Jiekun Huang, 2014, Capitalizing on Capitol Hill: Informed Trading by Hedge Fund Managers, Working Paper, University of Illinois at UrbanaChampaign.

[26] Gordon, Sanford, and Catherine Hafer, 2005, Flexing Muscle: Corporate Political Expenditures as Signals to the Bureaucracy, American Political Science Review 99, $245-261$.

[27] Gropp, Reint, Christian Grundl, and Andre Guettler, 2014, The Impact of Public Guarantees on Bank Risk Taking: Evidence from a Natural Experiment, Review of Finance 18, 457-448.

[28] Grossman, Gene, and Elhanan Helpman, 2001, Special Interest Politics (MIT Press, Cambridge).

[29] Heckman, James, Hidehiko Ichimura, and Petra Todd, 1997, Matching as an Econometric Evaluation Estimator: Evidence from Evaluating a Job Training Programme, Review of Economic Studies 64, 605-654.

[30] Heckman, James, Hidehiko Ichimura, and Petra Todd, 1998, Matching as an Econometric Evaluation Estimator, Review of Economic Studies 65, 261-294.

[31] Hsiao, Cheng, 2003, Analysis of Panel Data (Cambridge University Press, Cambridge).

[32] Igan, Deniz, and Prachi Mishra, 2012, Three's Company: Wall Street, Capitol Hill, and K Street, Working Paper, International Monetary Fund.

[33] Igan, Deniz, Prachi Mishra, and Thierry Tressel, 2012, A Fistful of Dollars: Lobbying and the Financial Crisis, NBER Macroeconomics Annual 26, 195-230.

[34] Ioannidou, Vasso, 2005, Does Monetary Policy Affect the Central Bank's Role in Bank Supervision? Journal of Financial Intermediation 14, 58-85.

[35] Jayaratne, Jith, and Philip Strahan, 1996, The Finance-Growth Nexus: Evidence from Bank Branch Deregulation, Quarterly Journal of Economics 111, 639-670.

[36] Johnson, Simon, and James Kwak, 2011, 13 Bankers: The Wall Street Takeover and the Next Financial Meltdown (Pantheon Books, New York). 
[37] Kane, Edward, 2012, Missing Elements in US Financial Reform: A Kübler-Ross Interpretation of the Inadequacy of the Dodd-Frank Act, Journal of Banking and Finance 36, 654-661.

[38] Kerr, William, William Lincoln, and Prachi Mishra, 2014, The Dynamics of Firm Lobbying, American Economic Journal: Economic Policy, forthcoming.

[39] King, Gary, and Langche Zeng, 2001, Logistic Regression in Rare Events Data, Political Analysis 9, 137-163.

[40] Kroszner, Randall, and Philip Strahan, 1996, Regulatory Incentives and the Thrift Crisis: Dividends, Mutual-to-Stock Conversions, and Financial Distress, Journal of Finance 51, 1285-1319.

[41] Kroszner, Randall, and Philip Strahan, 1999, What Drives Deregulation? Economics and Politics of the Relaxation of Bank Branching Restrictions, Quarterly Journal of Economics 114, 1437-1467.

[42] Laeven, Luc, and Ross Levine, 2009, Bank Governance, Regulation, and Risk Taking, Journal of Financial Economics 93, 259-275.

[43] Laeven, Luc, and Fabián Valencia, 2013, Systemic Banking Crises Database, IMF Economic Review 61, 225-270.

[44] Lancaster, Tony, 2000, The Incidental Parameter Problem Since 1948, Journal of Econometrics 95, 391-413.

[45] Lucca, David, Amit Seru, and Francesco Trebbi, 2014, The Revolving Door and Worker Flows in Banking Regulation, Journal of Monetary Economics 65, 17-32.

[46] McCubbins, Mathew, Roger Noll, and Barry Weingast, 1999, Political Control of Bureaucracy, in Peter Newman, ed.: The New Palgrave Dictionary of Economics and the Law (Palgrave-MacMillan, London).

[47] Mian, Atif, Amir Sufi, and Francesco Trebbi, 2010, The Political Economy of the US Mortgage Default Crisis, American Economic Review 100, 1967-1998.

[48] Mian, Atif, Amir Sufi, and Francesco Trebbi, 2013, The Political Economy of the Subprime Mortgage Credit Expansion, Quarterly Journal of Political Science 8, $373-408$.

[49] Neyman, Jerzy, and Elizabeth Scott, 1948, Consistent Estimates Based on Partially Consistent Observations, Econometrica 16, 1-32.

[50] Peek, Joe, Eric Rosengren, and Geoffrey Tootell, 1999, Is Bank Supervision Central to Central Banking? Quarterly Journal of Economics 114, 629 - 653. 
[51] Peltzman, Sam, 1976, Towards a More General Theory of Regulation, Journal of Law and Economics 19, 211-240.

[52] Perotti, Enrico, and Paolo Volpin, 2007, Politics, Investor Protection and Competition, ECGI Finance Working Paper No. 162/2007.

[53] Reinhart, Carmen, and Kenneth Rogoff, 2011, From Financial Crash to Debt Crisis, American Economic Review, 101, 1676-1706.

[54] Richter, Brian, Krislert Samphantharak, and Jeffrey Timmons, 2009, Lobbying and Taxes, American Journal of Political Science 53, 893-909.

[55] Roy, Arthur, 1952, Safety First and the Holding of Assets, Econometrica 20, $431-449$.

[56] Shive, Sophie, and Margaret Forster, 2014, The Revolving Door for Financial Regulators, Working Paper, University of Notre Dame.

[57] Shleifer, Andrei, and Robert Vishny, 1993, Corruption, Quarterly Journal of Economics 103, 599-617.

[58] Shleifer, Andrei, and Robert Vishny, 1994, Politicians and Firms, Quarterly Journal of Economics 109, 995-1025.

[59] Stigler, George, 1971, The Theory of Economic Regulation, Bell Journal of Economics and Management Science 2, 3-21.

[60] Yu, Frank, and Xiaoyun Yu, 2012, Corporate Lobbying and Fraud Detection, Journal of Financial and Quantitative Analysis 46, 1865-1891.

\section{A Definition of Variables}

\section{A.1 Regulatory Enforcement Actions}

Severe action dummy: dummy variable equal to one if Formal written agreements, Cease and desist orders, Prompt corrective action directive, and/or Deposit insurance threats are observed during the year, and zero otherwise.

Less severe action dummy: dummy variable equal to one if enforcement actions against Personnel and individuals, Formal memoranda of understanding, Hearing notices, Sanctions due to HMDA violation and/or other actions and fines are observed during the year, and zero otherwise. 
Formal written agreements: the number of formal agreements observed during the year.

Cease and desist orders: the number of cease and desist orders during the year.

Prompt corrective action directives: the number of prompt Corrective actions during the year.

Deposit insurance threats: the number of deposits insurance threats during the year.

\section{A.2 Risk Taking}

$Z$-score: the sum of return on assets and the equity-to-asset ratio divided by the standard deviation of the return on assets, calculated over a three-year rolling time window. Formally, the Z-score is equal to $\left(R O A+\frac{E}{A}\right) / \sigma(R O A)$, where $R O A$ is the bank's return on assets (i.e., $\left.\frac{\pi}{A}\right), \frac{E}{A}$ denotes its equity-to-asset ratio, and $\sigma(\pi / A)$ is the standard deviation of $R O A$. I use a three-year rolling time window for the $\sigma(R O A)$ to allow for sufficient variation in the denominator of the Z-score. This approach avoids that Z-scores are exclusively driven by variation in the levels of capital $(E)$ and profitability $(\pi)$. In unreported sensitivity analyses, I use different time windows and the results are unchanged. The Z-score is an accounting-based measure of banks' distance to default. Default is defined as a state in which losses surmount equity $(E<-\pi)$. The probability of default can therefore be expressed as $\operatorname{Prob}\left(-R O A<\frac{E}{A}\right)$. If profits are normally distributed, then the inverse of the probability of default equals $\left(R O A+\frac{E}{A}\right) / \sigma(R O A)$. I follow the literature by defining the inverse of the probability of default as the Z-score; thus, a higher Z-score implies a lower probability of default. In other words, the Z-score measures the number of standard deviations below the mean by which returns has to fall to wipe out bank equity. Because the Z-score is highly skewed, I use the natural logarithm of (1+Z-score), which is normally distributed (see Figure 3). For brevity, I use the label "Z-score" in referring to the natural logarithm of Z-score in the paper.

ROA volatility: the standard deviation of return on assets (ROA).

Nonperforming loans to total loans: loans 90 days or more past due but still accruing interest plus nonaccrual loans divided by total loans.

Nonaccrual loans to total loans: nonaccrual loans divided by total loans.

\section{A.3 Lobbying}

Lobbying dummy: dummy variable equal to one if the bank is active in lobbying during the year, and zero otherwise. "Active" means that the bank has at least hired once a 
lobbying firm or filed a lobbying report.

Revolving door dummy: dummy variable equal to one if the bank employs at least one revolving door lobbyist during the year. A revolving door lobbyist is an individual who serves or has served in public offices and moves to being employed as lobbyist; for more information about the methodology employed, see the CRP website.

Lobbying expenditures: dollar amount spent on lobbying during the year.

\section{A.4 Financials and Demographics}

Capital adequacy: Tier 1 capital divided by risk-weighted assets. Tier 1 risk-based capital ratio is the amount of a bank's capital relative to the risk profile of its assets. Broadly speaking, this criterion evaluates the extent to which a bank can absorb potential losses. Tier 1 capital comprises the more liquid subset of bank's capital, whose largest components include common stock, paid-in-surplus, retained earnings, and noncumulative perpetual preferred stock. The denominator of the ratio is computed as follows: all assets are divided into risk classes (defined by regulators), where more risky assets are assigned higher weights than less risky assets, thus contributing more to the denominator of the ratio. The idea behind is that banks, whose asset composition is riskier, need a greater amount of capital to remain sufficiently capitalized.

Asset quality: the negative of loan and lease allowance scaled by total loans. This ratio measures the adequacy of the allowance created by the bank to absorb losses on nonperforming loans. For ease of interpretation, this ratio is included with a negative sign so that greater values reflect higher asset quality. In the robustness section, I also test an alternative measure: the negative of net losses divided by total loans and leases. This alternative measure evaluates the overall condition of a bank's portfolio. A higher proportion of net losses indicates lower asset quality.

Management quality: the negative of the uniformly weighted moving average of the number of enforcement actions against personnel and individuals using three lagged years and the current year. In the robustness section, I also use the negative of the number of enforcement actions against personnel and individuals during the year.

Earnings: return on assets (ROA), measured as the ratio of the annualized net income in the trailing quarter to average total assets. In the robustness section, I also use the ratio of net interest income to earning assets.

Liquidity: the ratio of cash to deposits.

Sensitivity to market risk: the ratio of the absolute difference (gap) between short-term assets and short-term liabilities to earnings assets. This ratio measures the sensitivity to 
interest rate risk. The primary focus of risk analysis by regulators is on interest rate risk. The gap between both short-term assets and liabilities approximates the net amount of assets or liabilities that need to be repriced within one year, affecting in turn earnings. A higher gap reflects a higher interest rate risk.

Deposit-to-asset ratio: the ratio of total deposits to total book assets.

Leverage: the debt to equity ratio. For robustness, I also use an alternative measure: the ratio of total equity to total book assets.

Total core deposits: the deposits made in a bank's natural demographic market. This is a measure of the size of a bank's stable source of funds for their lending base.

Size: the natural logarithm of total assets. For brevity, I use the label "size" in referring to the natural logarithm of total assets in the paper.

Age: age (in years) of the bank.

\section{B Additional Robustness Tables}

Table B1: Impact of Lobbying on the Probability of a Severe Enforcement Action: Linear Probability Models

This table presents estimates from linear probability models explaining the likelihood of a severe enforcement action. The dependent variable is Severe action dummy. Models (1)-(3) are estimated for the full sample (i.e., the 1999-2012 interval). Models (4)-(6) are estimated for the crisis sample (i.e., the 2007-09 period). All models use the same set of control variables as in Table 6, except the state fixed fixed which are replaced by bank fixed effects. This table only reports the coefficients of variables of interest for brevity. All variables are defined in Appendix A. Robust standard errors clustered by bank are in parentheses. ${ }^{*}, * *$, and ${ }^{* * *}$ indicate significance at the $10 \%, 5 \%$, and $1 \%$ levels, respectively.

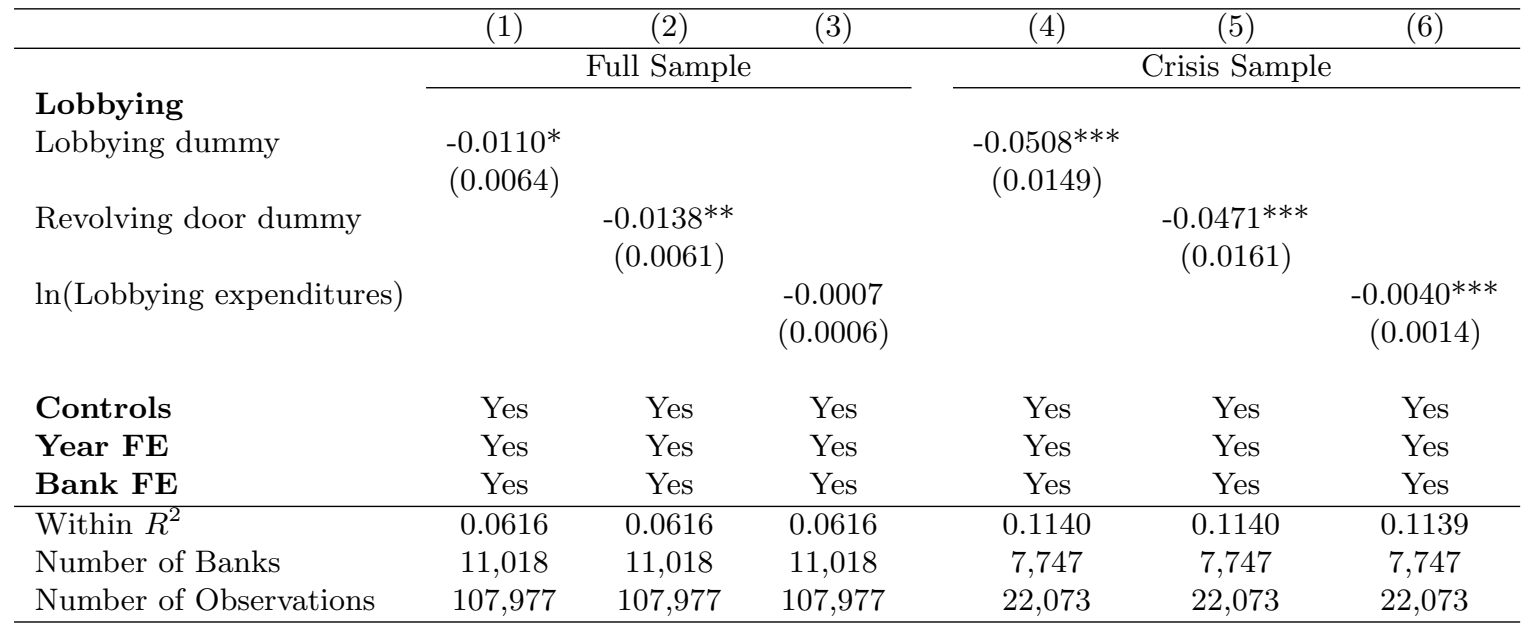




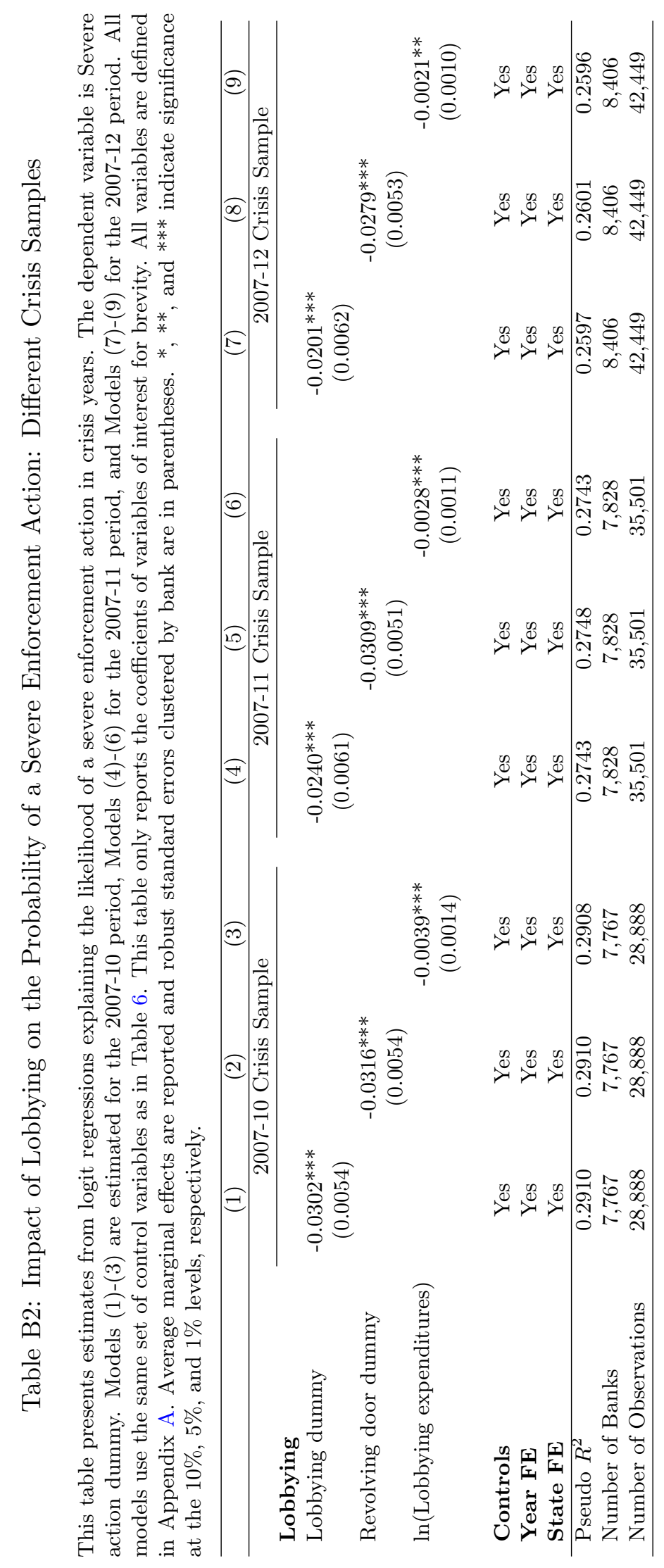




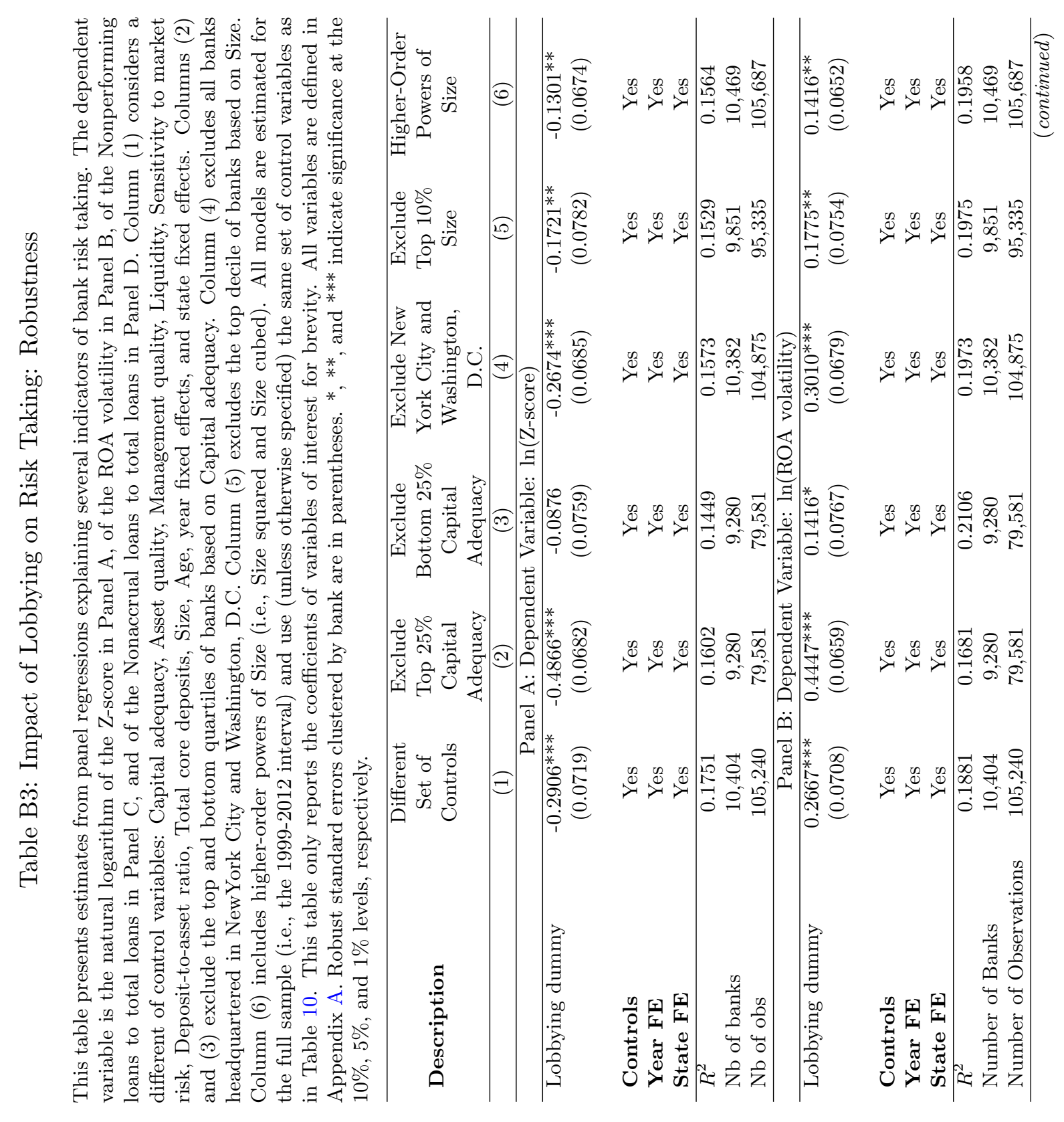




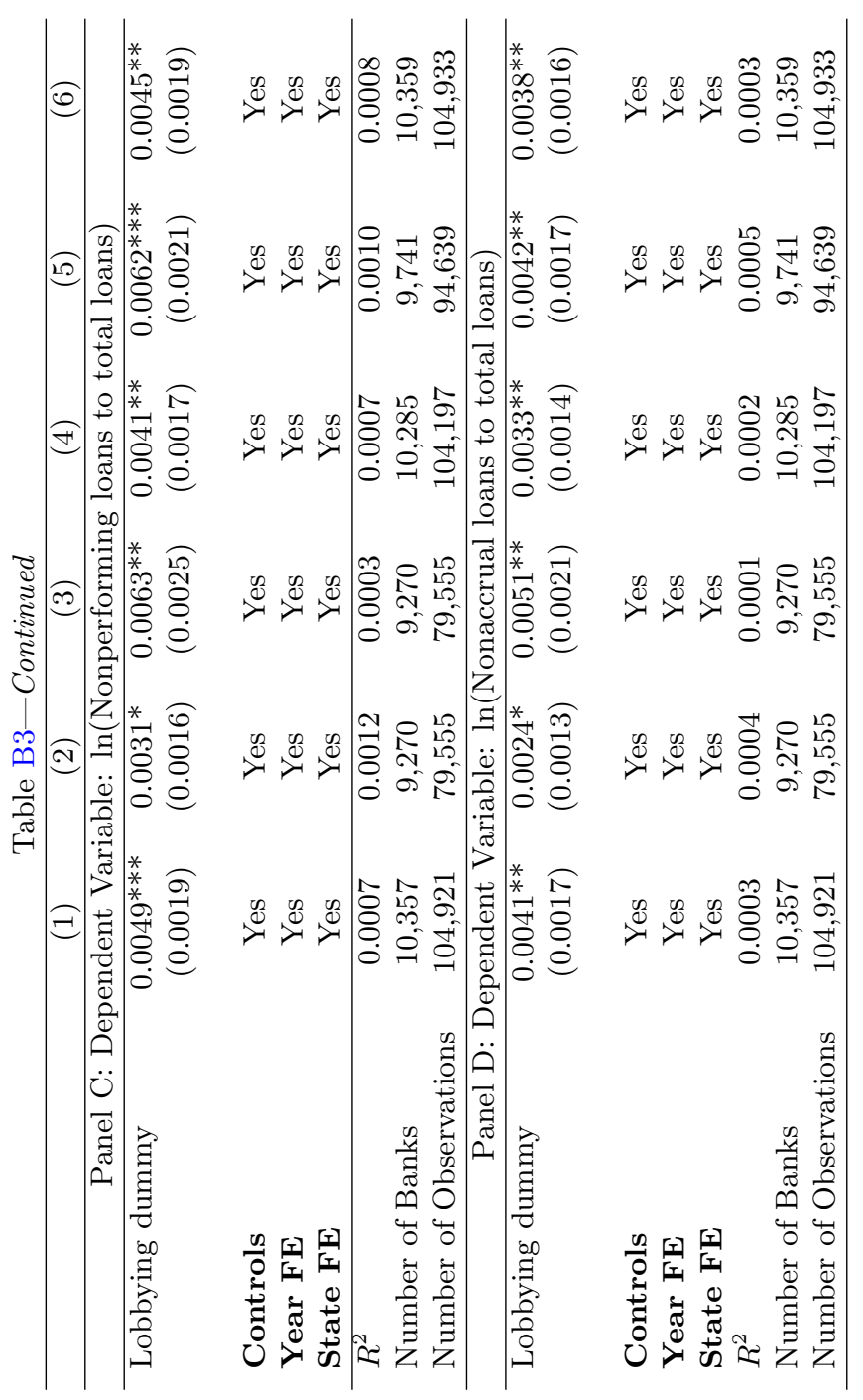



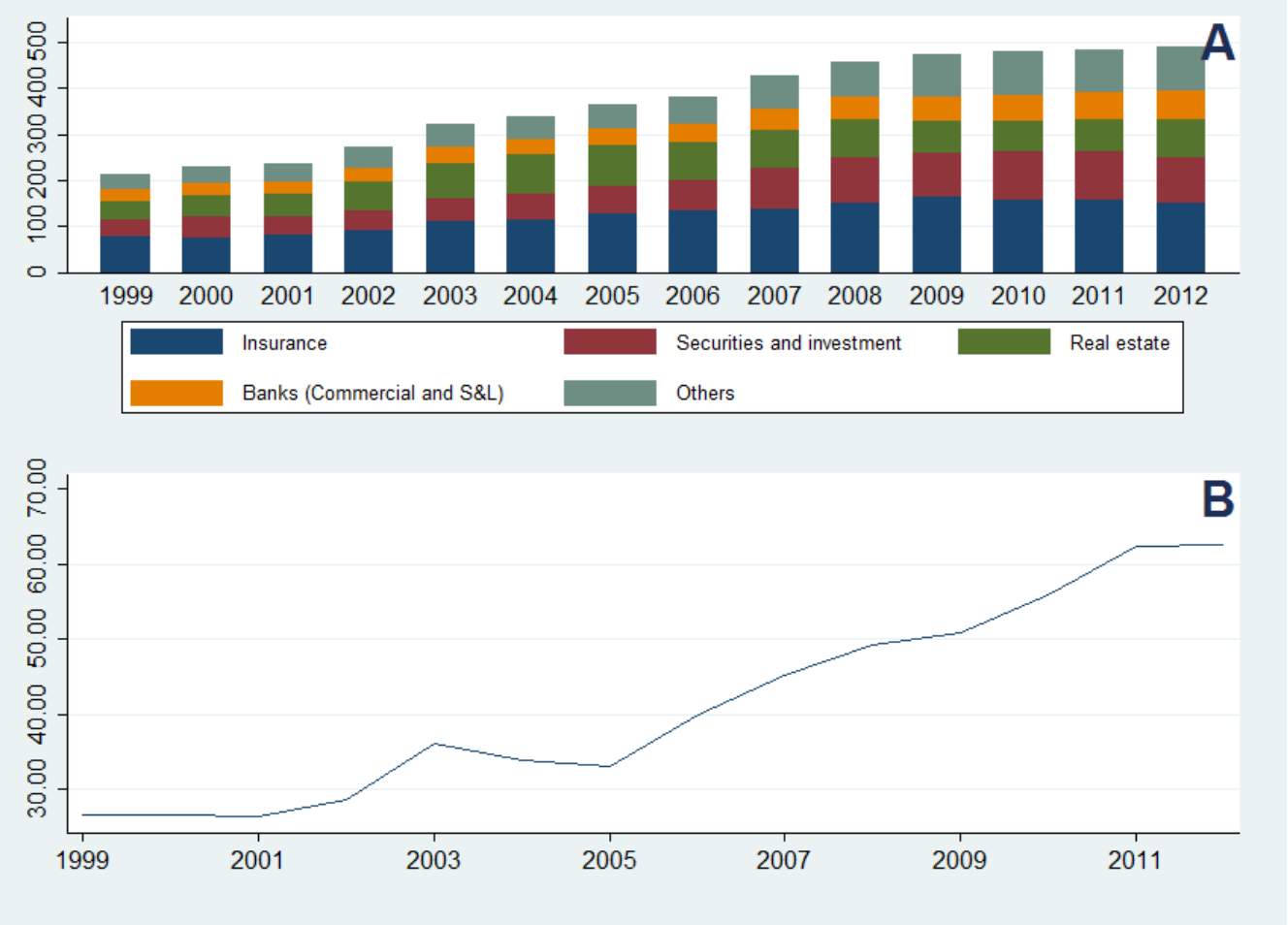

Figure 1: Financial Sector Distribution of Lobbying Expenditures

This figure presents the evolution of lobbying expenditures. Figure A shows the total lobbying expenditures (in $\$ 100$ million) by financial institutions over time. The financial sector is classified into: (1) Insurance companies, (2) securities and investment companies, (3) real estate companies, (4) commercial and savings banks, and (5) other types of financial firms. Figure B shows the total lobbying expenditures (in $\$ 100$ million) for the banking industry (i.e., commercial and savings banks) over time. Source: CRP. 

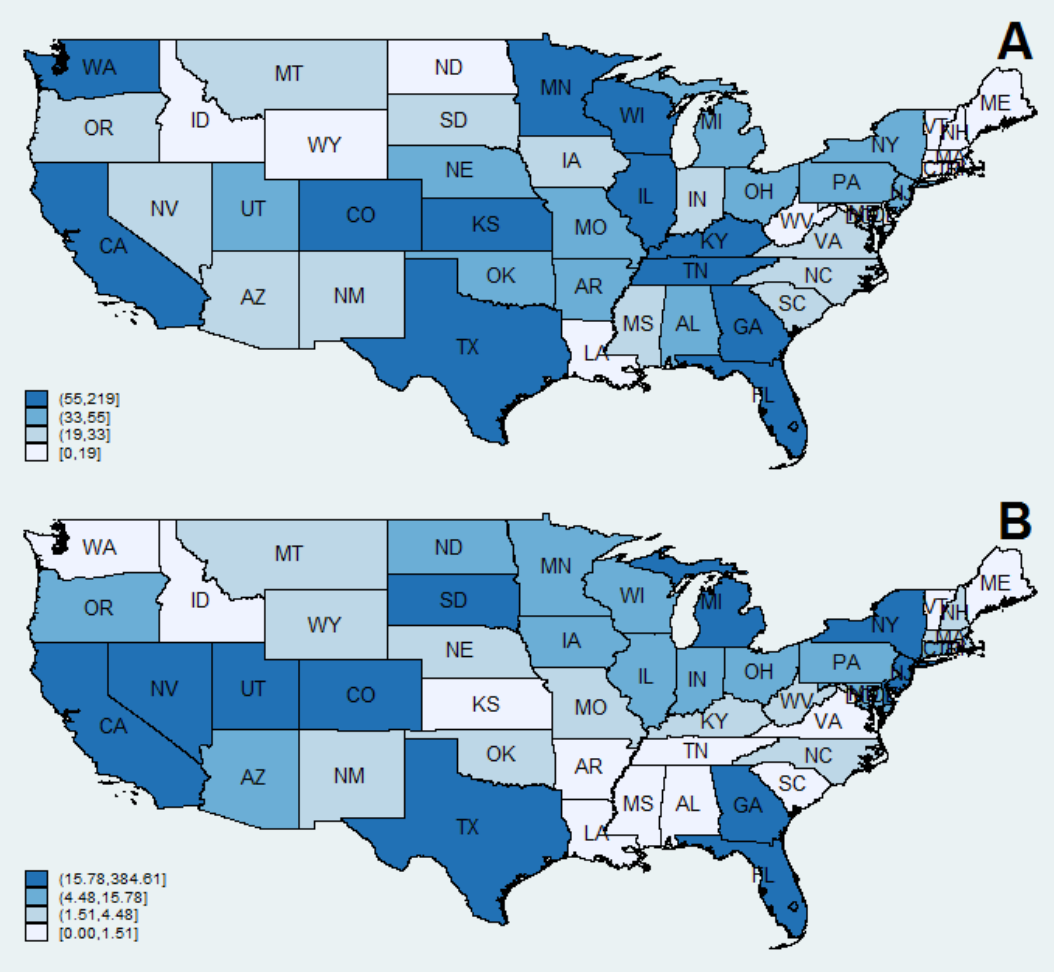

Figure 2: State Distribution of Regulatory Enforcement Actions and Lobbying Expenditures

This figure presents the concentration of regulatory enforcement actions and total lobbying expenditures by states. Figure A shows the state distribution of the total number of severe enforcement actions in the sample. Figure B shows the sum of lobbying expenditures (in $\$ 100$ million) by commercial and savings banks in the sample. Sources: SNL Financial and CRP. 


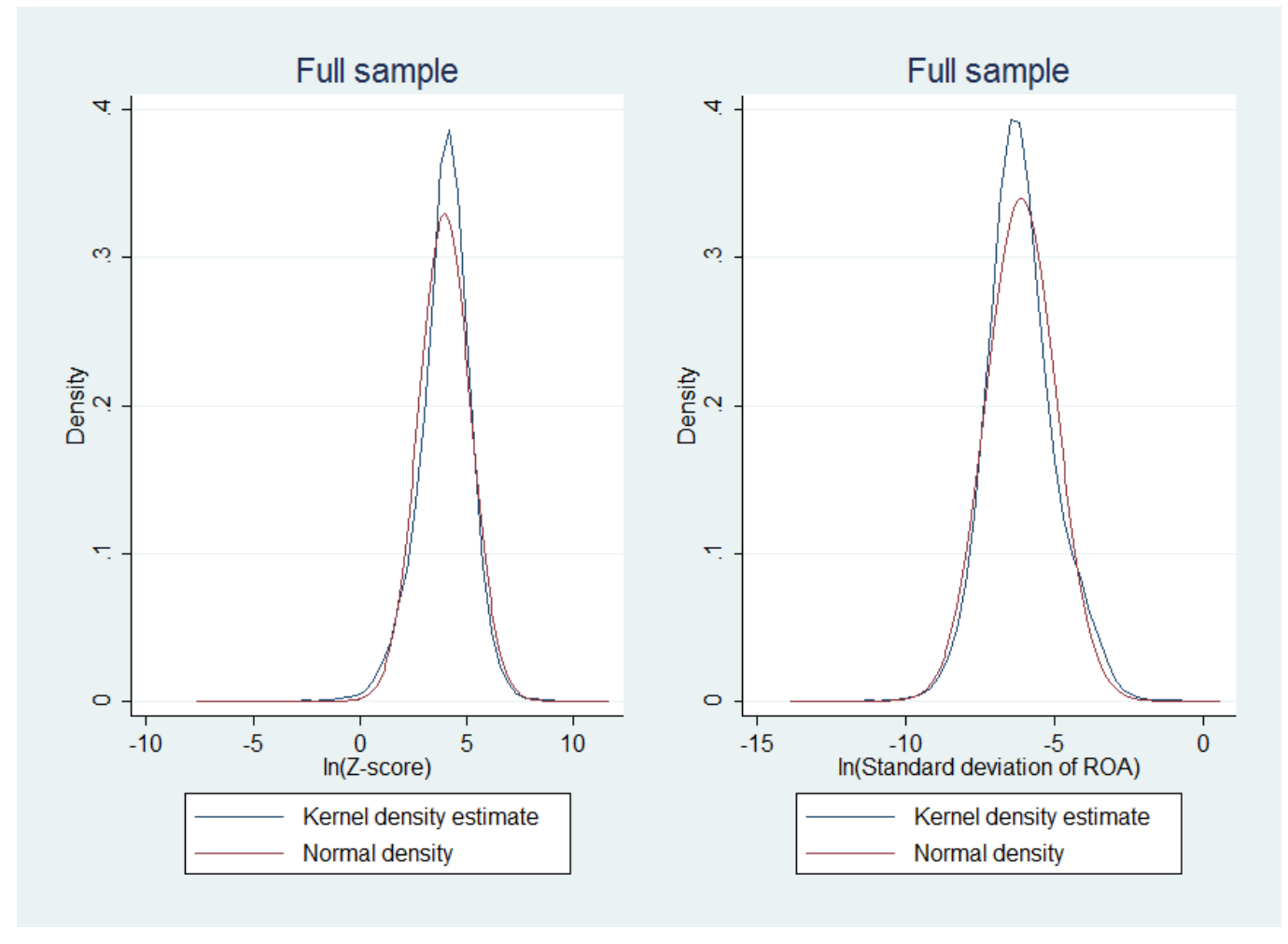

Figure 3: Kernel Densities of Z-score and ROA volatility

This figure reports the kernel densities of the natural logarithm of both Z-score and ROA volatility for the full sample. These variables are defined in Appendix A. Source: SNL Financial. 


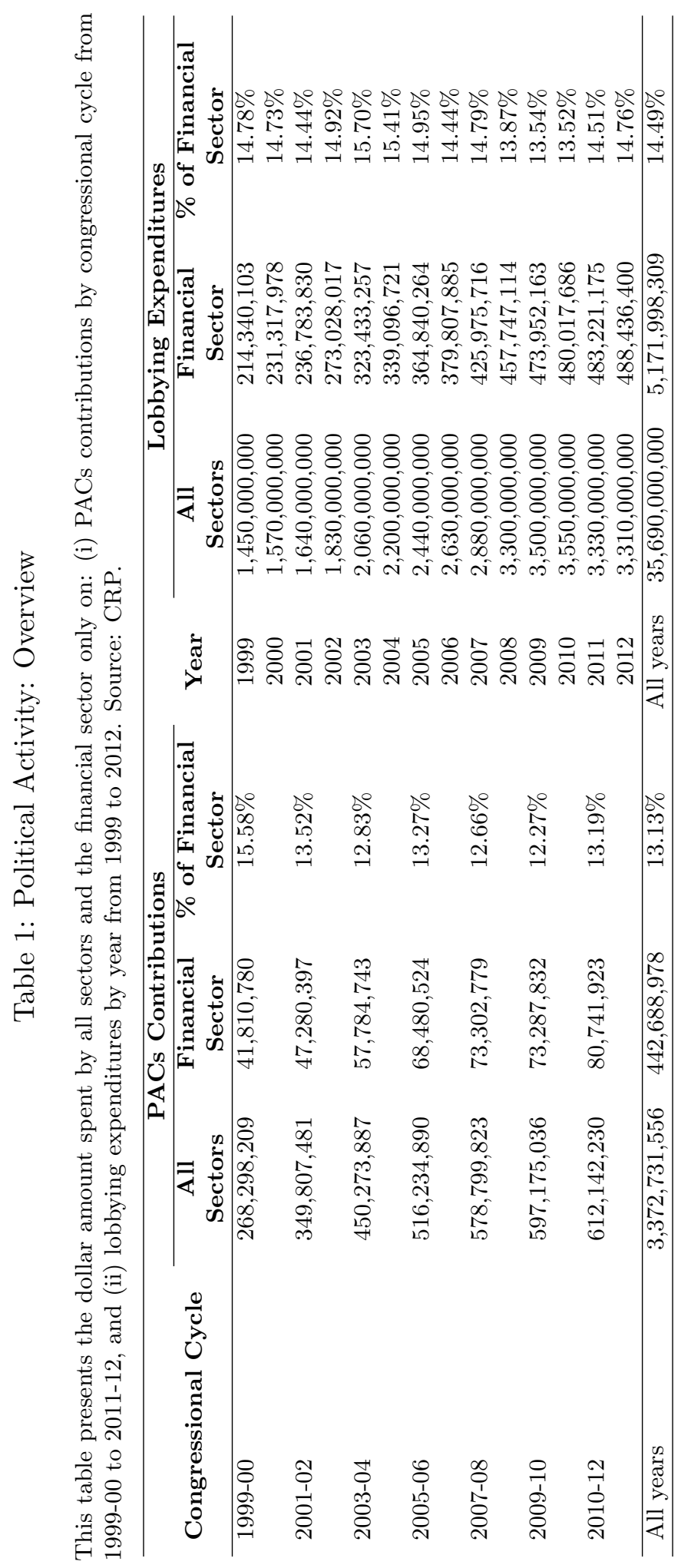




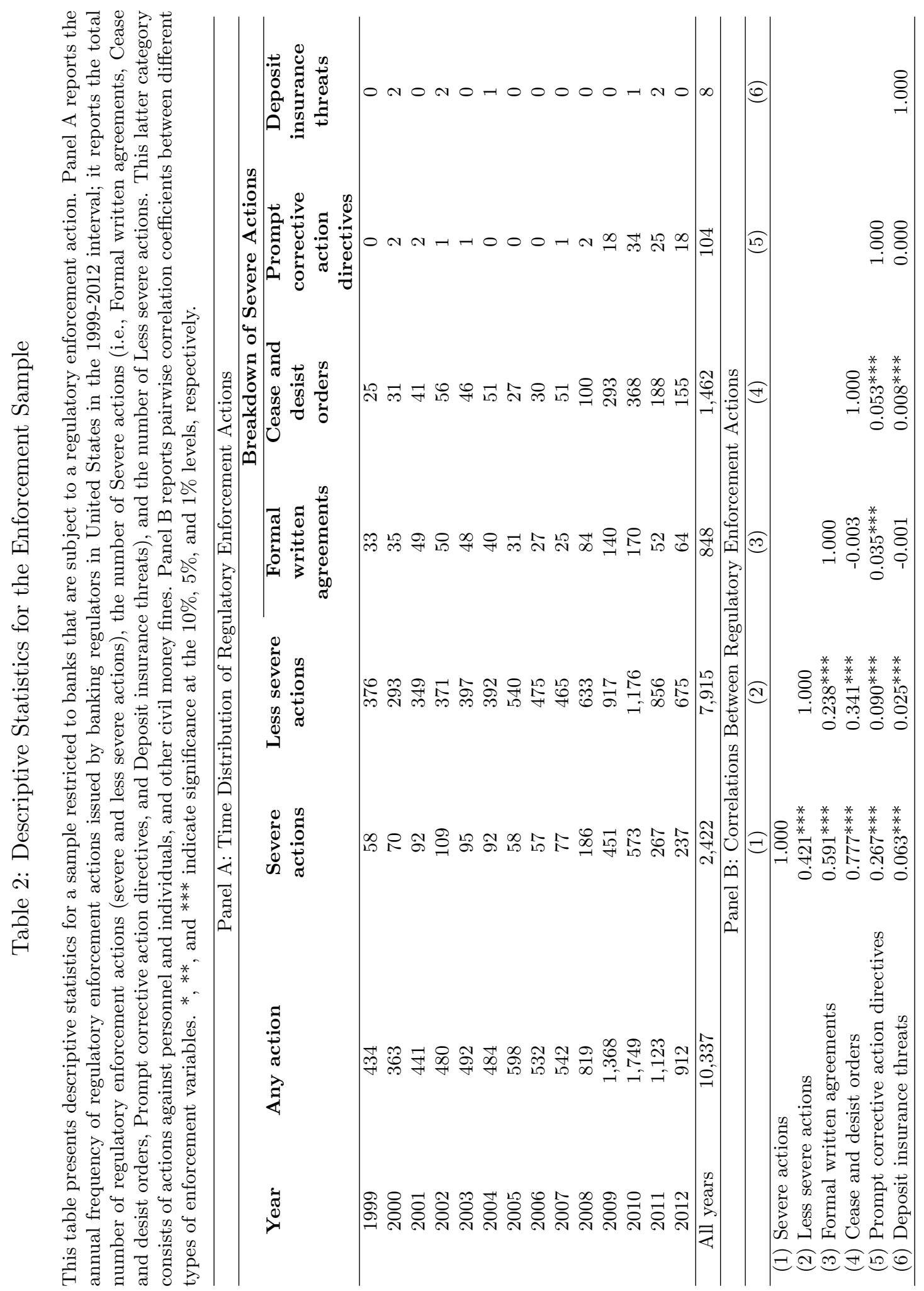




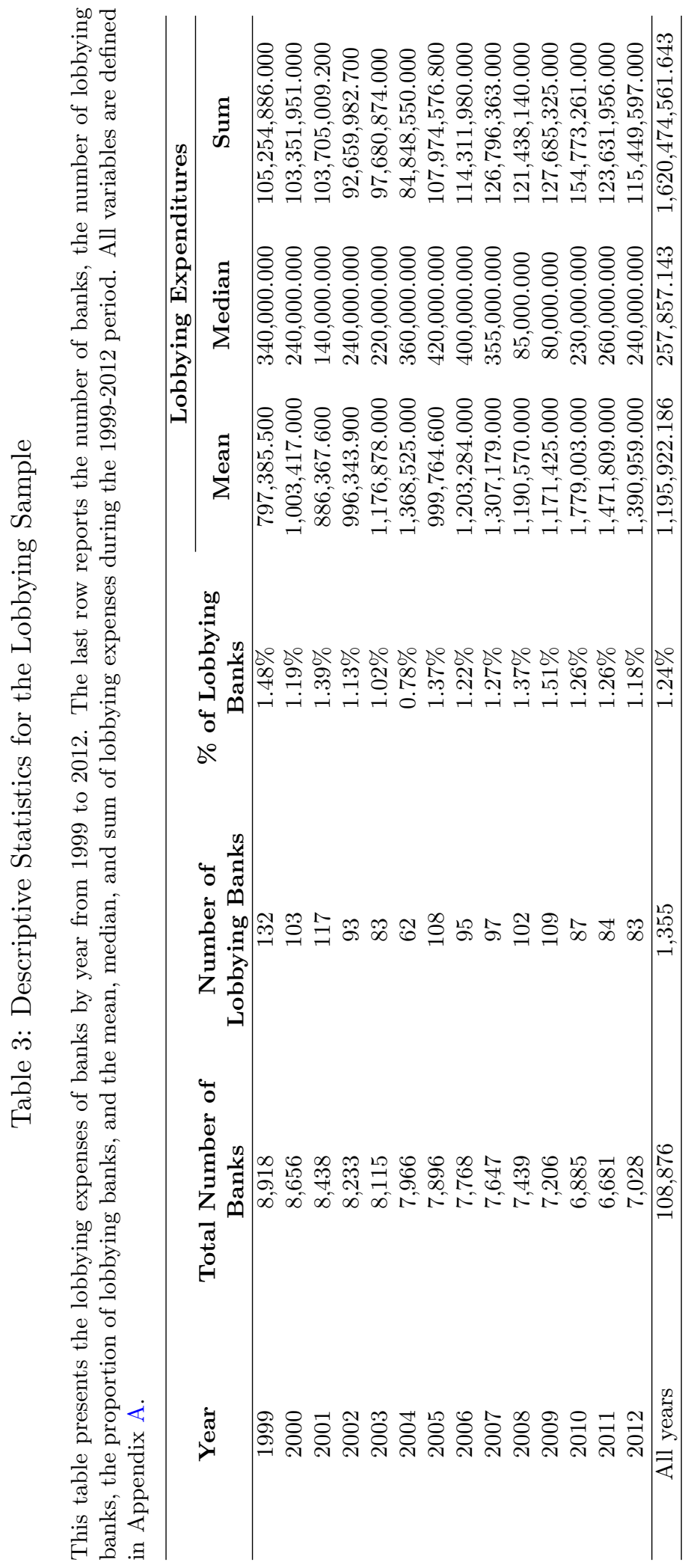




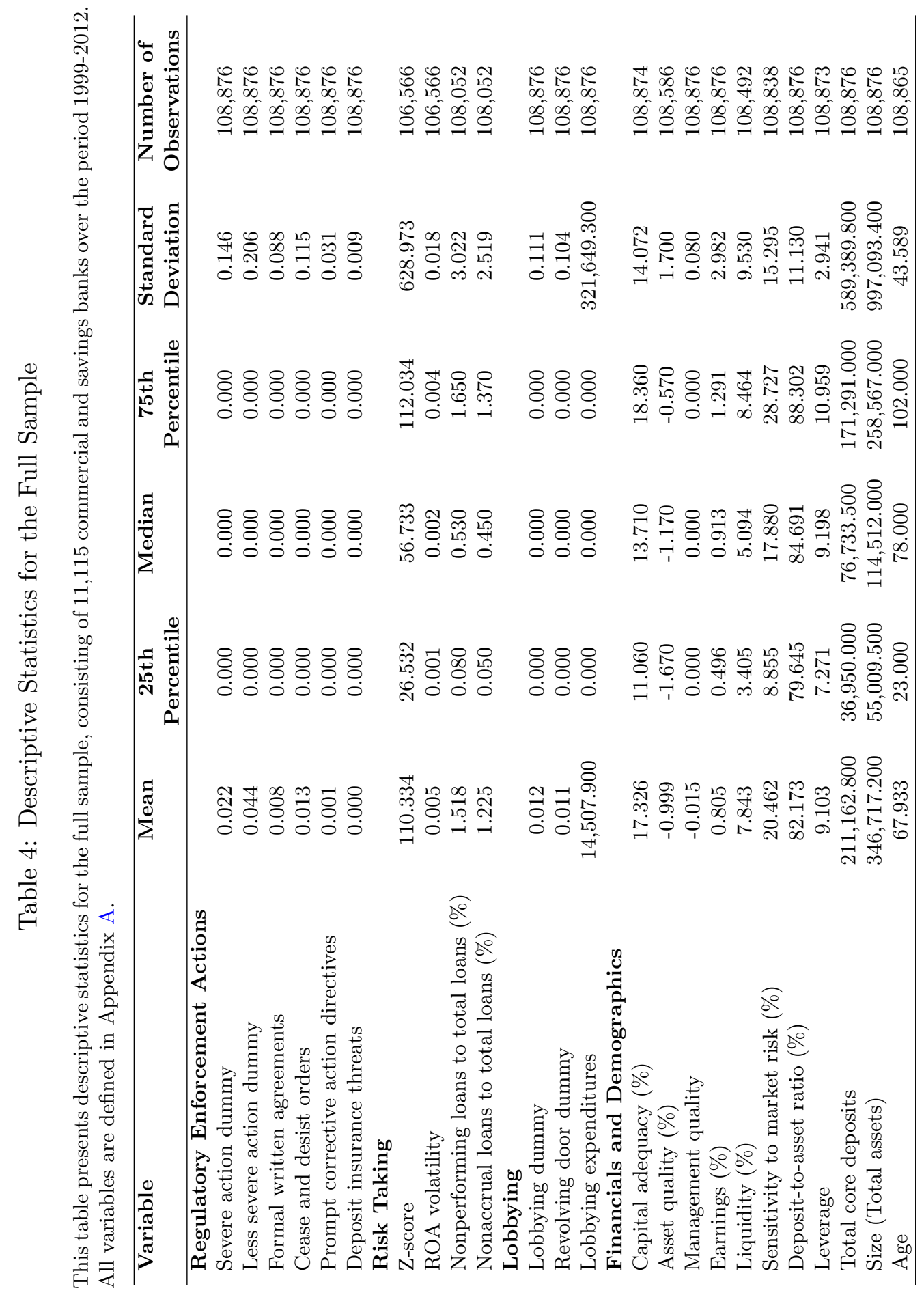


Table 5: Characteristics of Banks Subject (Not Subject) to a Severe Enforcement Action

This table reports the mean value of risk, lobbying, financial and demographic variables of banks that are subject (not subject) to a severe enforcement action. The last column reports the $p$-values of a test of difference in the means between banks subject and not subject to a severe action. All variables are defined in Appendix A.

\begin{tabular}{lccc}
\hline Variable & $\begin{array}{c}\text { Severe Actions } \\
\text { (Mean) }\end{array}$ & $\begin{array}{c}\text { No Actions } \\
\text { (Mean) }\end{array}$ & $\begin{array}{c}\text { Difference } \\
(p \text {-value) }\end{array}$ \\
\hline Risk Taking & & & \\
$\ln ($ Z-score) & 2.274 & 3.994 & 0.000 \\
$\ln$ (ROA volatility) & -4.773 & -6.173 & 0.000 \\
$\ln$ (Nonperforming loans to total loans) & 0.072 & 0.013 & 0.000 \\
$\ln$ (Nonaccrual loans to total loans) & 0.059 & 0.011 & 0.000 \\
Lobbying & & & \\
Lobbying dummy & 0.009 & 0.013 & 0.107 \\
Revolving door dummy & 0.007 & 0.011 & 0.044 \\
$\ln ($ Lobbying expenditures) & 0.109 & 0.155 & 0.113 \\
Financials and Demographics & & & \\
Capital adequacy (\%) & 13.121 & 17.420 & 0.000 \\
Asset quality (\%) & -1.962 & -0.977 & 0.000 \\
Management quality & -0.033 & -0.015 & 0.000 \\
Earnings (\%) & -1.675 & 0.861 & 0.000 \\
Liquidity (\%) & 10.379 & 7.786 & 0.000 \\
Sensitivity to market risk (\%) & 19.767 & 20.477 & 0.025 \\
Deposit-to-asset ratio (\%) & 84.822 & 82.114 & 0.000 \\
Leverage & 11.301 & 9.054 & 0.000 \\
$\ln$ (Total core deposits) & 11.578 & 11.276 & 0.000 \\
Size & 12.060 & 11.755 & 0.000 \\
Age & 53.075 & 68.265 & 0.000 \\
\hline
\end{tabular}


Table 6: Impact of Lobbying on the Probability of a Severe Enforcement Action: Base Models

This table presents estimates from logit regressions explaining the likelihood of a severe enforcement action. The dependent variable is Severe action dummy. Models (1)-(3) are estimated for the full sample (i.e., the 1999-2012 interval). Models (4)-(6) are estimated for the crisis sample (i.e., the 2007-09 period). All the regressions control for the six components derived from the CAMELS rating system (Capital adequacy, Asset quality, Management quality, Earnings, Liquidity, and Sensitivity to market risk), Deposit-to-asset ratio, Leverage, Total core deposits, Size, Age, year fixed effects, and state fixed effects. All variables are defined in Appendix A. Average marginal effects are reported and robust standard errors clustered by bank are in parentheses. *, **, and *** indicate significance at the $10 \%, 5 \%$, and $1 \%$ levels, respectively.

\begin{tabular}{|c|c|c|c|c|c|c|}
\hline & $(1)$ & $(2)$ & $(3)$ & $(4)$ & $(5)$ & $(6)$ \\
\hline & \multicolumn{3}{|c|}{ Full Sample } & \multicolumn{3}{|c|}{ Crisis Sample } \\
\hline Lobbying dummy & $\begin{array}{c}-0.0082^{* *} \\
(0.0033)\end{array}$ & & & $\begin{array}{c}-0.0195^{* * *} \\
(0.0053)\end{array}$ & & \\
\hline Revolving door dummy & & $\begin{array}{c}-0.0106^{* * *} \\
(0.0032)\end{array}$ & & & $\begin{array}{c}-0.0217^{* * *} \\
(0.0048)\end{array}$ & \\
\hline $\ln$ (Lobbying expenditures) & & & $\begin{array}{c}-0.0008^{*} \\
(0.0004)\end{array}$ & & & $\begin{array}{c}-0.0023^{* *} \\
(0.0011)\end{array}$ \\
\hline \multicolumn{7}{|c|}{ Financials and Demographics } \\
\hline Capital adequacy & $\begin{array}{c}-0.0830^{* * *} \\
(0.0183)\end{array}$ & $\begin{array}{c}-0.0827^{* * *} \\
(0.0183)\end{array}$ & $\begin{array}{c}-0.0830^{* * *} \\
(0.0183)\end{array}$ & $\begin{array}{c}-0.1063^{* * *} \\
(0.0392)\end{array}$ & $\begin{array}{c}-0.1064^{* * *} \\
(0.0391)\end{array}$ & $\begin{array}{c}-0.1063^{* * *} \\
(0.0392)\end{array}$ \\
\hline Asset quality & $\begin{array}{c}0.0610 \\
(0.0415)\end{array}$ & $\begin{array}{c}0.0604 \\
(0.0415)\end{array}$ & $\begin{array}{c}0.0609 \\
(0.0415)\end{array}$ & $\begin{array}{c}-1.1905^{* * *} \\
(0.1062)\end{array}$ & $\begin{array}{c}-1.1906^{* * *} \\
(0.1063)\end{array}$ & $\begin{array}{c}-1.1906^{* * *} \\
(0.1065)\end{array}$ \\
\hline Management quality & $\begin{array}{c}-0.0249^{* * *} \\
(0.0038)\end{array}$ & $\begin{array}{c}-0.0250^{* * *} \\
(0.0038)\end{array}$ & $\begin{array}{c}-0.0249^{* * * *} \\
(0.0038)\end{array}$ & $\begin{array}{c}-0.0192^{* *} \\
(0.0093)\end{array}$ & $\begin{array}{c}-0.0192^{* *} \\
(0.0093)\end{array}$ & $\begin{array}{c}-0.0192^{* *} \\
(0.0093)\end{array}$ \\
\hline Earnings & $\begin{array}{c}-0.6926^{* * *} \\
(0.0352)\end{array}$ & $\begin{array}{c}-0.6922^{\text {*** }} \\
(0.0352)\end{array}$ & $\begin{array}{c}-0.6922^{* * *} \\
(0.0352)\end{array}$ & $\begin{array}{c}-0.4745^{* * *} \\
(0.0555)\end{array}$ & $\begin{array}{c}-0.4747^{* * *} \\
(0.0557)\end{array}$ & $\begin{array}{c}-0.4739^{* * * *} \\
(0.0555)\end{array}$ \\
\hline Liquidity & $\begin{array}{c}0.0224^{* * *} \\
(0.0054)\end{array}$ & $\begin{array}{c}0.0226^{* * *} \\
(0.0054)\end{array}$ & $\begin{array}{c}0.0225^{* * *} \\
(0.0054)\end{array}$ & $\begin{array}{l}-0.0046 \\
(0.0144)\end{array}$ & $\begin{array}{l}-0.0046 \\
(0.0145)\end{array}$ & $\begin{array}{l}-0.0042 \\
(0.0144)\end{array}$ \\
\hline Sensitivity to market risk & $\begin{array}{c}-0.0183^{* * *} \\
(0.0040)\end{array}$ & $\begin{array}{c}-0.0182^{* * *} \\
(0.0040)\end{array}$ & $\begin{array}{c}-0.0183^{* * *} \\
(0.0040)\end{array}$ & $\begin{array}{c}-0.0153^{*} \\
(0.0093)\end{array}$ & $\begin{array}{l}-0.0152^{*} \\
(0.0093)\end{array}$ & $\begin{array}{l}-0.0154^{*} \\
(0.0093)\end{array}$ \\
\hline Deposit-to-asset ratio & $\begin{array}{c}0.0321^{* * *} \\
(0.0077)\end{array}$ & $\begin{array}{c}0.0320^{* * *} \\
(0.0077)\end{array}$ & $\begin{array}{c}0.0321^{* * *} \\
(0.0077)\end{array}$ & $\begin{array}{c}0.0331^{* *} \\
(0.0167)\end{array}$ & $\begin{array}{c}0.0332^{* *} \\
(0.0168)\end{array}$ & $\begin{array}{c}0.0328^{* *} \\
(0.0167)\end{array}$ \\
\hline Leverage & $\begin{array}{c}0.0018^{* * *} \\
(0.0002)\end{array}$ & $\begin{array}{c}0.0018^{* * *} \\
(0.0002)\end{array}$ & $\begin{array}{c}0.0018^{* * * *} \\
(0.0002)\end{array}$ & $\begin{array}{c}0.0026^{* * *} \\
(0.0005)\end{array}$ & $\begin{array}{c}0.0026^{* * *} \\
(0.0005)\end{array}$ & $\begin{array}{c}0.0026^{* * *} \\
(0.0005)\end{array}$ \\
\hline $\ln$ (Total core deposits) & $\begin{array}{c}-0.0031^{* * *} \\
(0.0009)\end{array}$ & $\begin{array}{c}-0.0031^{* * *} \\
(0.0009)\end{array}$ & $\begin{array}{c}-0.0031^{* * *} \\
(0.0009)\end{array}$ & $\begin{array}{l}-0.0026 \\
(0.0019)\end{array}$ & $\begin{array}{l}-0.0027 \\
(0.0020)\end{array}$ & $\begin{array}{l}-0.0026 \\
(0.0019)\end{array}$ \\
\hline Size & $\begin{array}{c}0.0035^{* * *} \\
(0.0010)\end{array}$ & $\begin{array}{c}0.0036^{* * *} \\
(0.0010)\end{array}$ & $\begin{array}{c}0.0035^{* * *} \\
(0.0010)\end{array}$ & $\begin{array}{c}0.0034 \\
(0.0022)\end{array}$ & $\begin{array}{c}0.0035 \\
(0.0023)\end{array}$ & $\begin{array}{c}0.0034 \\
(0.0022)\end{array}$ \\
\hline Age & $\begin{array}{l}-0.0000 \\
(0.0000)\end{array}$ & $\begin{array}{l}-0.0000 \\
(0.0000)\end{array}$ & $\begin{array}{l}-0.0000 \\
(0.0000)\end{array}$ & $\begin{array}{c}-0.0001^{*} \\
(0.0000)\end{array}$ & $\begin{array}{l}-0.0001^{*} \\
(0.0000)\end{array}$ & $\begin{array}{l}-0.0001^{*} \\
(0.0000)\end{array}$ \\
\hline Fixed Effects & & & & & & \\
\hline Year & Yes & Yes & Yes & Yes & Yes & Yes \\
\hline State & Yes & Yes & Yes & Yes & Yes & Yes \\
\hline Pseudo $R^{2}$ & 0.2347 & 0.2348 & 0.2346 & 0.2781 & 0.2785 & 0.2779 \\
\hline Number of Banks & 11,018 & 11,018 & 11,018 & 7,747 & 7,747 & 7,747 \\
\hline Number of Observations & 107,977 & 107,977 & 107,977 & 22,073 & 22,073 & 22,073 \\
\hline
\end{tabular}


Table 7: Impact of Lobbying on the Probability of a Severe Enforcement Action: IV Methods

This table presents estimates from regressions explaining the likelihood of a severe enforcement action. The dependent variable is Severe action dummy. Columns (1) and (2) report results from seemingly unrelated bivariate probit regressions, columns (3) and (4) report results from 2SLS regressions, and columns (5) and (6) report results from IV probit regressions. In each model, the instruments are the distance (in $\mathrm{km}$ ) of the bank's headquarters to Washington, D.C. and the initial (in 1998) number of offices held by the lobbying bank. Panel A reports results from the second-stage regressions, while Panel B reports results from the first-stage. All models are estimated for the full sample (i.e., the 1999-2012 interval) and use (unless otherwise specified) the same set of control variables as in Table 6 . This table only reports the coefficients of variables of interest for brevity. All variables are defined in Appendix A. Average marginal effects are reported (in columns (1), (2), and (5)) and robust standard errors clustered by bank are in parentheses. $*, * *$, and $* * *$ indicate significance at the $10 \%, 5 \%$, and $1 \%$ levels, respectively.

\begin{tabular}{|c|c|c|c|c|c|}
\hline & (1) & (2) & (3) & (4) & $(5)$ \\
\hline \multicolumn{6}{|c|}{ Panel A: Second-Stage Results } \\
\hline Lobbying & & & & & \\
\hline Lobbying dummy & $\begin{array}{c}-0.0130 * \\
(0.0079)\end{array}$ & & $\begin{array}{c}-0.0312^{* *} \\
(0.0147)\end{array}$ & & \\
\hline Revolving door dummy & & $\begin{array}{c}-0.0142^{*} \\
(0.0086)\end{array}$ & & $\begin{array}{c}-0.0430 * * \\
(0.0204)\end{array}$ & \\
\hline $\ln$ (Lobbying expenditures) & & & & & $\begin{array}{c}-0.1093^{*} \\
(0.0660)\end{array}$ \\
\hline Controls & Yes & Yes & Yes & Yes & Yes \\
\hline Year FE & Yes & Yes & Yes & Yes & Yes \\
\hline State FE & Yes & Yes & Yes & Yes & Yes \\
\hline Method of Estimation & Biprobit & Biprobit & $2 \mathrm{SLS}$ & $2 \mathrm{SLS}$ & IV Probit \\
\hline$R^{2}$ & - & - & 0.0805 & 0.0805 & - \\
\hline Number of Banks & 10,983 & 10,983 & 10,983 & 10,983 & 10,983 \\
\hline Number of Observations & 107,795 & 107,795 & 107,795 & 107,795 & 107,795 \\
\hline \multicolumn{6}{|c|}{ Panel B: First-Stage Results } \\
\hline Lobbying & & & & & \\
\hline Distance to DC & $\begin{array}{c}-0.0004^{* * *} \\
(0.0001)\end{array}$ & $\begin{array}{c}-0.0005^{* * *} \\
(0.0001)\end{array}$ & $\begin{array}{c}-0.0001^{* * *} \\
(0.0000)\end{array}$ & $\begin{array}{c}-0.0001^{* * *} \\
(0.0000)\end{array}$ & $\begin{array}{c}-0.0001 \\
(0.0000)\end{array}$ \\
\hline Initial market size & $\begin{array}{c}0.0075^{* * *} \\
(0.0008)\end{array}$ & $\begin{array}{c}0.0056^{* * *} \\
(0.0004)\end{array}$ & $\begin{array}{c}0.0021^{* * *} \\
(0.0001)\end{array}$ & $\begin{array}{c}0.0015^{* * *} \\
(0.0002)\end{array}$ & $\begin{array}{c}0.0229^{* * *} * \\
(0.0018)\end{array}$ \\
\hline Controls & Yes & Yes & Yes & Yes & Yes \\
\hline Year FE & Yes & Yes & Yes & Yes & Yes \\
\hline State FE & Yes & Yes & Yes & Yes & Yes \\
\hline$F$ test of excluded instruments & - & - & 88.2 & 52.27 & - \\
\hline Hansen $J$-statistic ( $p$-value) & - & - & 0.2467 & 0.2375 & - \\
\hline Wald test of $\rho=0$ ( $p$-value $)$ & 0.4275 & 0.7655 & - & - & 0.1648 \\
\hline$R^{2}$ & - & - & 0.0805 & 0.145 & - \\
\hline Number of Banks & 10,983 & 10,983 & 10,983 & 10,983 & 10,983 \\
\hline Number of Observations & 107,795 & 107,795 & 107,795 & 107,795 & 107,795 \\
\hline
\end{tabular}




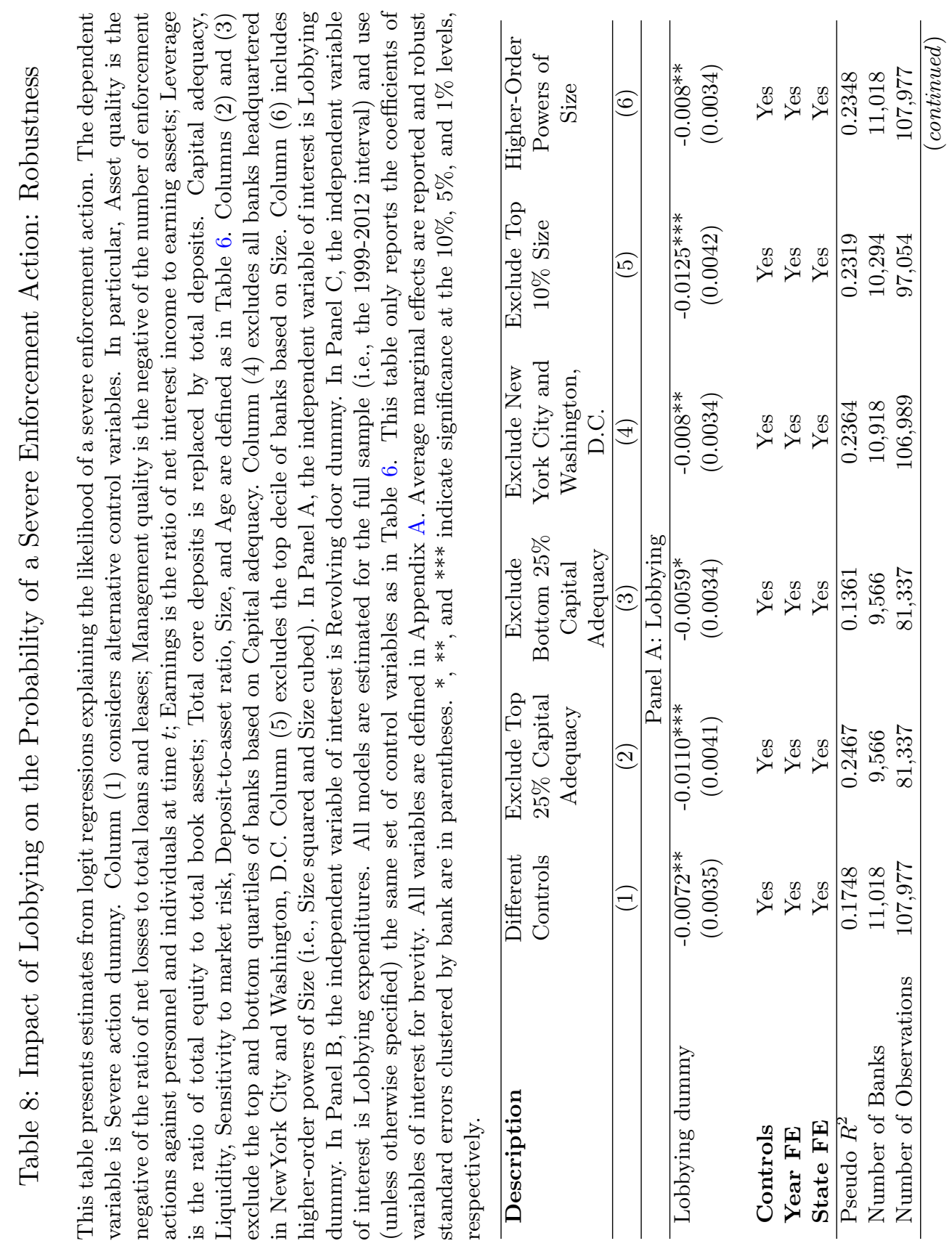




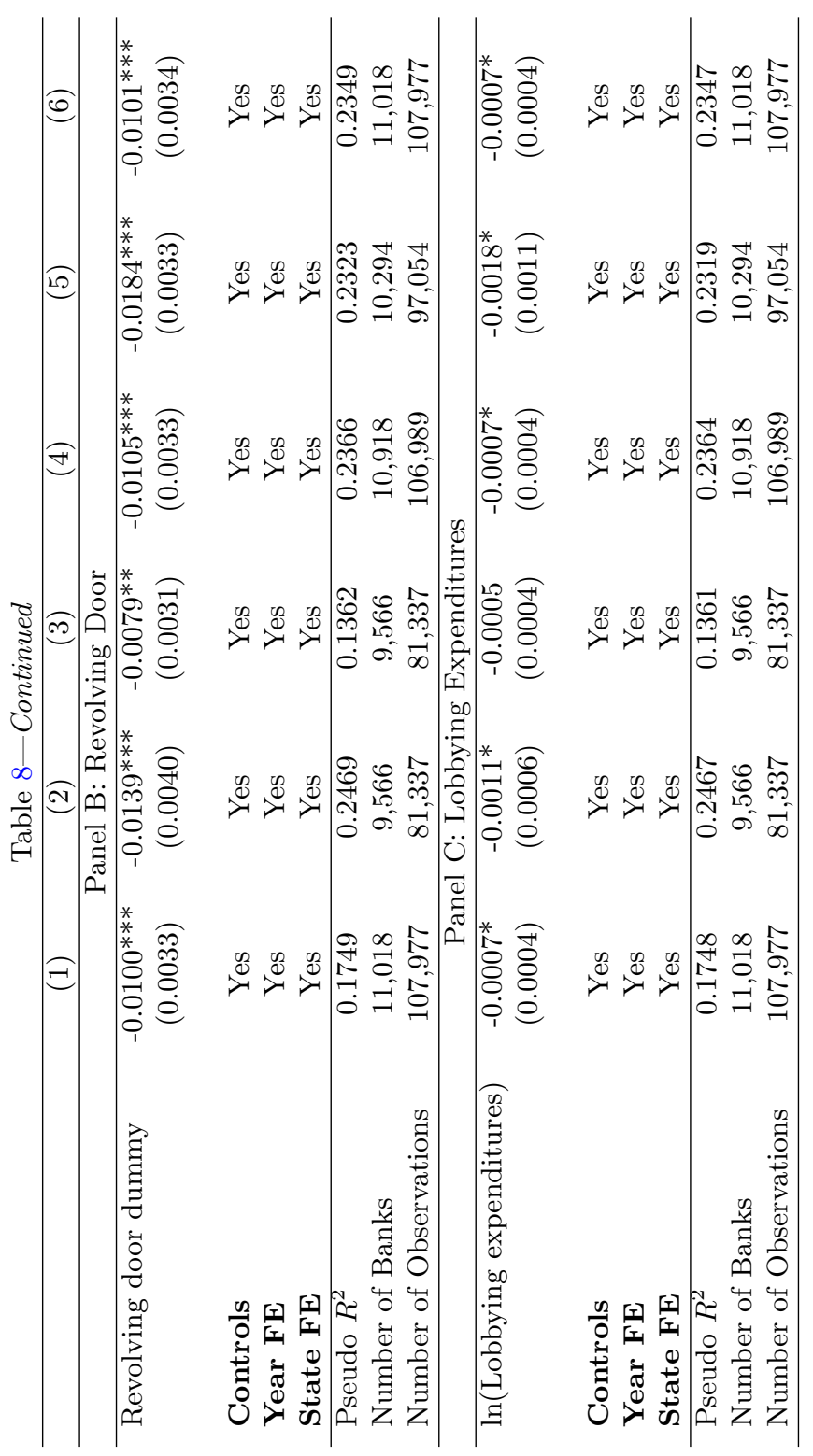


Table 9: Impact of Lobbying on Severe Enforcement Actions: Matching Methods

This table provides estimates of the mean difference between the likelihood of a severe enforcement action for lobbying banks and non-lobbying banks; i.e. the average treatment effect on the treated (ATT). Columns 1 and 3 report the ATT estimates, while columns 2 and 4 report the number of matched treated. For the estimation of the propensity score, I estimate unreported logit regressions where the dependent variable is Lobbying dummy and I match on the logarithm of the odds ratio of the propensity score. The independent variables are the Deposit-to-asset ratio, Leverage, Size, Age, year dummies, and state dummies. The estimators, which are described in detail in Heckman, Ichimura, and Todd (1997, 1998), are defined as follows: Near neighbor chooses for each lobbying bank, the $n$ non-lobbying banks with closest propensity scores, and uses the arithmetic average of the $n$ non-lobbying banks. I use $n=1,10,50$, and 100 with caliper $=0.01$. I allow replacement, i.e. each matching observation may be used more than once. Gaussian and Epanechnikov employ a weighted average of non-lobbying banks, with more weight given to nonlobbying banks with propensity scores that are closer to the lobbying bank propensity score. For Gaussian and Epanechnikov, I specify a propensity score bandwidth $(h)$ that limits the sample of non-lobbying banks. I specify that $h=0.01$. The number of observations of the matched sample may be lower than the number of banks to be matched because the logit model may not find a suitable match, such as when the propensity score of a lobbying bank falls outside of the support of non-lobbying bank propensity scores. All variables are defined in Appendix A. Standard errors are in parentheses under the parameter estimates. ${ }^{*},{ }^{* *}$, and ${ }^{* * *}$ indicate significance at the $10 \%$, $5 \%$, and $1 \%$ levels, respectively.

\begin{tabular}{|c|c|c|c|c|}
\hline \multirow[t]{3}{*}{ Estimator } & $\mathrm{ATT}$ & $\begin{array}{c}\text { Number of } \\
\text { matches }\end{array}$ & $\mathrm{ATT}$ & $\begin{array}{c}\text { Number of } \\
\text { matches }\end{array}$ \\
\hline & (1) & (2) & (3) & (4) \\
\hline & \multicolumn{2}{|c|}{ Lobbying dummy } & \multicolumn{2}{|c|}{ Revolving door dummy } \\
\hline Near neighbor $(n=1$; caliper $=0.01)$ & $\begin{array}{c}-0.0158^{* * *} \\
(0.0064)\end{array}$ & 1,267 & $\begin{array}{c}-0.0136^{* *} \\
(0.0068)\end{array}$ & 1,103 \\
\hline Near neighbor $(n=10 ;$ caliper $=0.01)$ & $\begin{array}{c}-0.0129 * * * \\
(0.0045)\end{array}$ & 1,267 & $\begin{array}{c}-0.0183^{* * *} \\
(0.0050)\end{array}$ & 1,103 \\
\hline Near neighbor $(n=50 ;$ caliper $=0.01)$ & $\begin{array}{c}-0.0142^{* * *} \\
(0.0044)\end{array}$ & 1,267 & $\begin{array}{c}-0.0169 * * * \\
(0.0048)\end{array}$ & 1,103 \\
\hline Near neighbor $(n=100 ;$ caliper $=0.01)$ & $\begin{array}{c}-0.0142^{* * *} \\
(0.0043)\end{array}$ & 1,267 & $\begin{array}{c}-0.0167^{* * *} \\
(0.0047)\end{array}$ & 1,103 \\
\hline Gaussian & $\begin{array}{c}-0.0108 * * * \\
(0.0042)\end{array}$ & 1,352 & $\begin{array}{c}-0.0129 * * * \\
(0.0044)\end{array}$ & 1,193 \\
\hline Epanechnikov & $\begin{array}{c}-0.0115^{* * *} \\
(0.0043)\end{array}$ & 1,352 & $\begin{array}{c}-0.0135^{* * *} \\
(0.0046)\end{array}$ & 1,193 \\
\hline
\end{tabular}


Table 10: Impact of Lobbying on Risk Taking: Base Models

This table presents estimates from regressions explaining several indicators of bank risk taking. The dependent variable is the natural logarithm of the Z-score in column (1), of the ROA volatility in column (2), of the Nonperforming loans to total loans in column (3), and of the Nonaccrual loans to total loans in column (4). Panel A reports results from panel regressions, in which the independent variable of interest is Lobbying dummy. Panel B reports results from panel regressions, in which the independent variable of interest is Revolving door dummy. Panel $\mathrm{C}$ reports results from panel regressions, in which the independent variable of interest is Lobbying expenditures. All the regressions control for the Deposit-to-asset ratio, Total core deposits, Size, Age, year fixed effects, and state fixed effects. All models are estimated for the full sample (i.e., the 1999-2012 interval). This table only reports the coefficients of variables of interest for brevity. All variables are defined in Appendix A. Robust standard errors clustered by bank are in parentheses. ${ }^{*},{ }^{* *}$, and ${ }^{* * *}$ indicate significance at the $10 \%, 5 \%$, and $1 \%$ levels, respectively.

\begin{tabular}{|c|c|c|c|c|}
\hline Variable & $\ln (\mathrm{Z}$-score $)$ & $\begin{array}{c}\ln (\mathrm{ROA} \\
\text { volatility })\end{array}$ & $\begin{array}{l}\text { ln(Nonperfor- } \\
\text { ming loans } \\
\text { to total loans) }\end{array}$ & $\begin{array}{c}\ln \text { (Nonaccrual } \\
\text { loans to total } \\
\text { loans })\end{array}$ \\
\hline & (1) & $(2)$ & $(3)$ & (4) \\
\hline \multicolumn{5}{|c|}{ Panel A: Lobbying } \\
\hline Lobbying dummy & $\begin{array}{c}-0.2334^{* * *} \\
(0.0692)\end{array}$ & $\begin{array}{c}0.2711^{* * *} \\
(0.0679)\end{array}$ & $\begin{array}{c}0.0049^{* * *} \\
(0.0019)\end{array}$ & $\begin{array}{c}0.0042^{* * *} \\
(0.0016)\end{array}$ \\
\hline Controls & Yes & Yes & Yes & Yes \\
\hline Year FE & Yes & Yes & Yes & Yes \\
\hline State FE & Yes & Yes & Yes & Yes \\
\hline Overall $R^{2}$ & 0.1561 & 0.1973 & 0.0008 & 0.0003 \\
\hline Number of Banks & 10,469 & 10,469 & 10,359 & 10,359 \\
\hline Number of Observations & 105,687 & 105,687 & 104,933 & 104,933 \\
\hline \multicolumn{5}{|c|}{ Panel B: Revolving Door } \\
\hline Revolving door dummy & $\begin{array}{c}-0.2004^{* * *} \\
(0.0695)\end{array}$ & $\begin{array}{c}0.2176^{* * * *} \\
(0.0680)\end{array}$ & $\begin{array}{c}0.0045^{* * *} \\
(0.0018)\end{array}$ & $\begin{array}{c}0.0039^{* *} \\
(0.0016)\end{array}$ \\
\hline Controls & Yes & Yes & Yes & Yes \\
\hline Year FE & Yes & Yes & Yes & Yes \\
\hline State FE & Yes & Yes & Yes & Yes \\
\hline Overall $R^{2}$ & 0.1561 & 0.1970 & 0.0008 & 0.0003 \\
\hline Number of Banks & 10,469 & 10,469 & 10,359 & 10,359 \\
\hline Number of Observations & 105,687 & 105,687 & 104,933 & 104,933 \\
\hline \multicolumn{5}{|c|}{ Panel C: Lobbying Expenditures } \\
\hline $\ln$ (Lobbying expenditures) & $\begin{array}{c}-0.0185^{* * *} \\
(0.0058)\end{array}$ & $\begin{array}{c}0.0227^{* * *} \\
(0.0058)\end{array}$ & $\begin{array}{l}0.0004^{* *} \\
(0.0002)\end{array}$ & $\begin{array}{c}0.0003^{* *} \\
(0.0002)\end{array}$ \\
\hline Controls & Yes & Yes & Yes & Yes \\
\hline Year FE & Yes & Yes & Yes & Yes \\
\hline State FE & Yes & Yes & Yes & Yes \\
\hline Overall $R^{2}$ & 0.1562 & 0.1973 & 0.0008 & 0.0003 \\
\hline Number of Banks & 10,469 & 10,469 & 10,359 & 10,359 \\
\hline Number of Observations & 105,687 & 105,687 & 104,933 & 104,933 \\
\hline
\end{tabular}

